\title{
The Development and Status of Sexual Orientation Discrimination under International Human Rights Law
}

\author{
Dominic McGoldrick*
}

\begin{abstract}
This article assesses the development, status and recognition of a prohibition on sexual orientation discrimination as a matter of international human rights law. The State practice examined appears to reveal fundamental divisions on this issue. The article considers whether there are any treaty-based obligations that support the prohibition on sexual orientation as an existing right. Having examined the national, regional and international human rights jurisprudence on sexual orientation discrimination, the article considers the possible ways forward in policy terms, given the continued opposition from a significant body of States. More specifically, it discusses the most appropriate legal and strategic responses at national, regional and international levels to manage or bridge the divisions between States on the issue.
\end{abstract}

Keywords: sexual orientation - equality - non-discrimination - right to privacy - right to family life - human rights obligations - interpretation of human rights treaties

\section{Introduction}

This article assesses the development, status and recognition of a prohibition on sexual orientation discrimination as a matter of international human rights law. ${ }^{1}$ Supporters of the prohibition on such discrimination have sought to subsume it within established human rights - such as non-discrimination, privacy, family, expression and association - and within established human rights procedures and institutions. ${ }^{2}$ Opponents of the prohibition have, to various degrees, rejected these arguments. They see the prohibition as a 'new'

\footnotetext{
* Professor of International Human Rights Law, University of Nottingham.

${ }^{1}$ See also Sanders, 'Human Rights and Sexual Orientation in International Law' (2002) 25 International Journal of Public Administration 13; Kirby, 'Sexuality and International Law: The New Dimension' (2014) European Human Rights Law Review 350.

2 This article does not specifically deal with gender identity issues but many of the arguments presented would also apply in that context. See McGill, 'SOGI....So What? Sexual Orientation, Gender Identity and Human Rights Discourse at the United Nations' (2014) 3 Canadian Journal of Human Rights 1.
} 
additional right to which they have not and are not going to consent. ${ }^{3}$ Approached from a positivist perspective, State practice appears to reveal fundamental divisions on this issue. It is submitted that the variations in State practice are such that there is no credible argument for such an existing prohibition as a matter of general or universal customary international law. There is either no customary rule or there are a very large number of persistent objectors. ${ }^{4}$ There is stronger evidence for regional customs, for example in Western Europe. However, as we shall see, within any wider European region there are significant dissenters.

The focus in this article is on whether there are any treaty-based obligations that support the prohibition on sexual orientation as an existing right. It considers how the interpretation and application of that right by various human rights bodies has accommodated the significant legislative and judicial practice from States - including many which are parties to the relevant treaties - and strong public opposition in many States, particularly linked to tradition, culture, religiosity and relative poverty, that is clearly inconsistent with such an interpretation and application. The widespread and significant opposition from States to this normative rise of the prohibition of sexual orientation discrimination has created a situation in which there is a very serious tension between what is asserted to be clear international human rights law and what are the practices of a large number of States from all regions of the world and marked regional differences. States have not made reservations to any prohibition on sexual orientation discrimination, presumably because they considered that the relevant treaties imposed no such obligation in the first place. ${ }^{5}$ Thus the effect of a 'living instrument' approach to the interpretation of international human rights law has the effect of placing them in violation, regardless of any original meaning. Having examined the national, regional and international human rights jurisprudence on sexual orientation discrimination the article considers the possible ways forward in policy terms, given the continued opposition from a significant body of States.

\footnotetext{
${ }^{3}$ See Mittelstaedt, 'Safeguarding the Rights of Sexual Minorities' (2008) 9 Chicago Journal of International Law 353.

${ }^{4}$ For the contrary view but citing examples of much more isolated opposition see Clavier, 'Objection Overruled: The Binding Nature of the International Norm Prohibiting Discrimination Against Homosexual and Transgendered Individuals' (2012) 35 Fordham International Law Journal 385.

${ }^{5}$ In any event the HRC has taken the view that a reservation to the obligation in Article 2 ICCPR to respect and ensure the rights, and to do so on a non-discriminatory basis would be contrary to the object and purpose of the Covenant, see GC 24 on Reservations, CCPR/C/21/Rev.1/Add.6, para 9.
} 
More specifically, it discusses the most appropriate legal and strategic responses at national, regional and international levels to manage or bridge the divisions between States on the issue.

The issues considered in this article are of enormous legal, practical and human significance. The fundamental legal and practical issues in play relate to the interpretation of human rights treaties in terms of authority to interpret, the scope of obligations, methodology, consent, the relevance or otherwise of State consensus and applicability or otherwise of a margin of appreciation. As for the human cost, in 2013 UN Secretary-General Ban Ki-Moon stated that discrimination on grounds of sexual orientation was 'one of the great, neglected human rights challenges of our time. ${ }^{6}$ Report after report on sexual orientation issues, from all regions of the world, has evidenced violence, repression, exclusion and stigmatization against individuals on the basis of their sexual orientation, commonly grounded in discrimination. ${ }^{7}$

Following this introduction, Part 2 examines the rise of sexual orientation discrimination within international human rights law. Part 3 examines developments within the UN human rights systems, whilst Part 4 examines developments in the regional human rights systems. In Part 5 consideration is given to support for and opposition to sexual orientation discrimination as a human rights issue at the national level. The evidence relates to a series of critical thematic areas - criminalisation of homosexual activities and the introduction of homophobic hate crimes, the express prohibition of discrimination on grounds of sexual orientation, Gay Pride marches and homosexual propaganda laws, and persecution on grounds of sexual orientation in the context of Asylum and Refugees. In Parts 2-5 the predominant focus is international, regional and national jurisprudence and legislative developments. Reference is also made to significant political, institutional and policy developments as well as IGO, and civil society initiatives. Obviously many of these developments are interrelated. Causal links between them need to be

\footnotetext{
${ }^{6}$ UN SG, 'Message to The Oslo Conference on Human Rights, Sexual Orientation and Gender Identity' (15-16 April 2013), Summary of the Conference and Toolkit, available at http://www.hrsogi.org (hereinafter Oslo Conference Report).

${ }^{7}$ See Discriminatory Laws and Practices and Acts of Violence Against Individuals based on their Sexual Orientation and Gender Identity, A/HRC/19/41, 17 November 2011 (hereinafter OHCHR Report 2011); Homophobia, Transphobia and Discrimination on Grounds of Sexual Orientation and Gender Identity in the EU Member States, European Union Agency for Fundamental Rights (FRA), Vienna, 2011, available at http://fra.europa.eu/sites/default/files/fra_uploads/1759-FRA-2011-Homophobia-UpdateReport_EN.pdf; European Union lesbian, gay, bisexual and transgender survey, FRA, Vienna, 2013, available at http://fra.europa.eu/sites/default/files/eu-lgbt-survey-results-at-aglance_en.pdf; Trappolin, Gasparini and Wintemute (eds), Confronting Homophobia in Europe Social and Legal Perspectives (Oxford: Hart, 2012).
} 
evaluated to provide the appropriate contextualisation of the issues discussed. ${ }^{8}$ Part 6 considers the consequences of the contested status of sexual orientation discrimination as an international human rights law issue. Part 7 sets out the possible legal and strategic responses to manage or bridge the divisions between States on the issue. Finally, Part 8 offers some concluding observations given the current lack of consensus.

\section{The Rise of Sexual Orientation Discrimination within international human rights} law

The emergence or addition of 'new' specific issues within the broad human rights movement always presents challenges. ${ }^{9}$ The rise of new rights has been described as complex, contingent, and contentious. ${ }^{10}$ As one human rights issue rises in prominence, other human rights issues are necessarily affected in absolute or relational terms. ${ }^{11}$ Thus discrimination based on sexual orientation has presented new challenges freedom of religion and for church autonomy. ${ }^{12}$ Those advocating for recognition of, and protection from, sexual orientation discrimination within international human rights law have certainly had their legal and policy successes. ${ }^{13}$ But as with any human rights advocacy movement, there are always setbacks stemming from political and social obstacles. ${ }^{14}$ Historically, advocacy on sexual orientation as a human rights issue proceeded by focussing on the interpretation and application of existing substantive rights obligations binding on States parties to human rights treaties, rather than arguing for the

\footnotetext{
${ }^{8}$ On the systemic influence of international courts and human rights bodies see Helfer and Voeten, 'International Courts as Agents of Legal Change: Evidence from LGBT Rights in Europe' (2014) International Organization 77.

${ }^{9}$ See Roseman and Miller, 'Normalizing Sex and its Discontents: Establishing Sexual Rights in International Law' (2011) 34 Harvard Journal of Law and Gender 313.

${ }^{10}$ See Clifford (ed), The International Struggle For New Human Rights (Pennsylvania: Univ Of Pennsylvania Press, 2008).

${ }^{11}$ See Johnson, Law, Religion and Homosexuality (Abingdon: Routledge, 2014).

${ }^{12}$ See Heinze, 'Sexual Orientation and International Law: A Study in the Manufacture of CrossCultural Sensitivity' (2001) 22 Michigan JIL 283; Heinze, Sexual Orientation: A Human Right (Dordrecht: Nijhoff, 1995); Wintemute, Sexual Orientation and Human Rights (Oxford: OUP, 1995); Richards, The Rise of Gay Rights and the Fall of the Birth Empire (Cambridge: CUP, 2013); Etherton, infra n 292.

${ }^{13}$ See Alston and Goodman, International Human Rights (OUP, 2013) at 220-38. On NGO and civil society advocacy on sexual and gender diversity at the UN and the EU see Swiebel, 'Lesbian, Gay, Bisexual and Transgender Human Rights: The Search for an International Strategy' (2009) 15 Contemporary Politics 19.

${ }^{14}$ See Altman and Symons, Queer Wars (Cambridge: Polity, 2016); De Burca, 'The Trajectories of European and American Anti-Discrimination Law' (2012) 60 The American Journal of Comparative Law 1.
} 
recognition of new human rights and new human rights instruments. ${ }^{15}$ This was critically important because, to the extent that it was successful, it meant that sexual orientation issues could and should be addressed within existing law and by existing human rights procedures and institutions, ${ }^{16}$ rather than arguing for new rights and new human rights instruments. ${ }^{17}$ The implicit assumption was, of course, that identification of sexual orientation issues in a 'human rights' discourse ${ }^{18}$ within existing mechanisms and institutions was a necessary, if not a sufficient, condition for having a positive impact on the lives of those concerned. ${ }^{19}$

Advocacy on sexual orientation discrimination as a human right aligned itself with nondiscrimination campaigns and social movements on the more traditional grounds such as race, gender and minorities. ${ }^{20}$ It then sought to extend that jurisprudence by analogy of reasoning or harm. ${ }^{21}$ Over time, however, efforts shifted to focussing on sexual orientation as a separate and distinct ground of discrimination. In this NGO's have played their part although sustained efforts had to be made to persuade national and international human rights NGOs to take on sexual orientation issues as part of their agendas. ${ }^{22}$

The centre of the debate in normative terms has been whether the treatment of discrimination on grounds of sexual orientation should be considered on a par with established

${ }^{15}$ See OHCHR, Born Free and Equal - Sexual Orientation and Gender Identity in International Human Rights Law, (2012), (hereinafter OHCHR Report 2012) available at http://www.ohchr.org/Documents/Publications/BornFreeAndEqualLowRes.pdf.

${ }^{16}$ My emphasis. Some view those procedures and institutions as problematic in terms of their understanding of sexuality issues, see Roseman and Miller, supra n 9.

${ }^{17}$ See $O H C H R$ Report 2011, supra n 7. Given the political differences between States, the idea of a Convention on the Elimination of Sexual Orientation Discrimination appears unrealistic. See Morgan, 'Sexual and Gender Rights and the United Nations Human Rights Framework: Towards a Resolution of the Debate?' available at ses.library.usyd.edu.au/bitstream/2123/5323/1/DISSERTATION_LMorgan.pdf

${ }^{18}$ On discourse and framing issues see Waites, "Critiques of "Sexual Orientation" and "Gender Identity" in Human Rights Discourse' (2009) 15 Contemporary Politics 137; McGill, supra n 2; Mertus, 'The Rejection of Human Rights Framings: The Case of LGBT Advocacy in the US' (2007) 29 Human Rights Quarterly 1036.

${ }^{19}$ See Kollman and Waites, 'The Global Politics of Lesbian, Gay, Bisexual and Transgender Human Rights: An Introduction' (2009) 15 Contemporary Politics 1.

${ }^{20}$ See Chan (ed), 'Protection of Sexual Minorities Since Stonewall' (2009) 13 The International Journal of Human Rights 121-492; Dotan, 'The Boundaries of Social Transformation through Litigation: Women's and LGBT Rights in Israel, 1970-2010' (2015) 48 Israel Law Review 3.

${ }^{21}$ On other analogies see Heinze, 'Cumulative Jurisprudence and Hate Speech: Sexual Orientation and Analogies to Disability, Age, and Obesity', in Hare and Weinstein (eds), Extreme Speech and Democracy (Oxford: OUP, 2009) 265.

${ }^{22}$ On debates with human rights NGOs on including sexual orientation issues see Mertus, supra n 18. Particularly important in strategic terms were recognition by Amnesty International and Human Rights Watch as the so-called gatekeepers of the NGO movement, ibid, at 1044-48. 
grounds such as racial or gender discrimination. To some extent the process of interpretation for national, regional and international bodies was easy - human rights are usually stated to apply to 'everyone'. Provisions prohibiting discrimination tend to follow the pattern of an open list and a reference to 'sex' and to 'other status'. Sexual orientation has then been interpreted to fall in either, or both, of these categories. This is seen as an application of the 'living instrument' approach to the interpretation of human rights treaties and consistent with their object and purpose. ${ }^{23}$ The final step is to argue that discrimination on grounds of sexual orientation can only be justified by particularly serious or weighty reasons. As this article will illustrate, international human rights institutions, particularly the European Court of Human Rights (ECtHR), the InterAmerican Court of Human rights (IACtHR) and the Human Rights Committee (HRC), have largely imitated each other's jurisprudence to reach these results.

\section{Developments within UN Human Rights Systems}

This Part examines the major developments and in part, the lack thereof, in the UN international human rights systems and organizations in order to ascertain the degree to which sexual orientation issues have been addressed within existing law and by existing human rights mechanisms and institutions. As we shall see, the cross-cutting nature of the non-discrimination guarantee means that sexual orientation issues are now addressed across the whole range of UN human rights mechanisms. ${ }^{24}$

(a) UN Bodies and Specialized Agencies

By comparison with some of the regional organizations, ${ }^{25}$ progress at the United Nations has been rather slower and more contested. ${ }^{26}$ Only in the 1990 s was significant attention

${ }^{23}$ There have been significant dissents arguing that the ECtHR's use of the living instrument approach has gone too far, as in $X v$. Austria, infra nn 158, 165.

${ }^{24}$ See OHCHR Report 2011, supra n 7, 36-53.

${ }^{25}$ See Part 4 infra.

${ }^{26}$ See McGill, supra n 2, 9-21; Roseman and Miller, supra n 9, 359-71; Corrêa, Petchesky and Parker, 'Inventing and Contesting Sexual Rights Within the UN' in Sexuality, Health and Human Rights (New York: Routledge, 2008) 164; Girard, 'Negotiating Sexual Rights and Sexual Orientation at the UN', in Parker et al (eds), Sex/Politics: Reports from the Frontlines (2007), available at www.sxpolitics.org/frontlines/book/index.php; Karsay et al, How far has SOGII advocacy come at the UN and where is it heading? ARC International, (September 2014) available at http://arc-international.net. 
directed to sexual orientation issues. ${ }^{27}$ Since then there have been, and continue to be, battles fought by NGOs concerned with LGBT rights to be accredited in international organizations and then to get LGBT issues onto their agendas. ${ }^{28}$ By 2008 a Joint Statement on the human rights of LGBT persons sent to the General Assembly, which reaffirmed 'the principle of non-discrimination which requires that human rights apply equally to every human being regardless of sexual orientation or gender identity', had the support of 66 States. ${ }^{29}$ However, it was met by a negative formal Response by 57 States. ${ }^{30}$ No formal resolutions were proposed then or subsequently because there has not been enough support for the adoption of an official resolution by the GA as a whole. Since 2003 GA resolutions on 'Extrajudicial, summary or arbitrary executions' have made reference to international law obligations to investigate killings of persons 'because of their sexual orientation or gender identity' ${ }^{31}$ In 2010 an amendment in the Third Committee removing the reference to sexual orientation was sponsored by Benin on behalf of the African Group and was adopted with 79 votes in favour, 70 against, 17 abstentions and 26 absent. However, in the Plenary GA the reference has been reinstated on a vote of 93 for, 55 against, and 27 abstentions.

In terms of the practice of the $\mathrm{UN}$ as an institution there is some evidence that the UN SG's supportive statements are not just rhetorical and symbolic but that the UN's practice as an institution and employer is consistent with them. UN agencies and organs such as UNDP, UNESCO, ILO, WHO, UNFPA, UNICEF and UNAIDS have integrated issues of sexual orientation and gender identity into their work. ${ }^{32}$ In 2014 the UN, which has some 43,000 staff, announced that it would globally extend its employee benefits to

\footnotetext{
${ }^{27}$ See Heinze, (1995) supra n 12; Sanders, 'Getting Lesbian and Gay Issues on the International Human Rights Agenda' (1996) 18 Human Rights Quarterly 67.

${ }^{28}$ See 'UN takes forward step on LGBT rights and backward step on sexual and reproductive rights' International service for Human Rights (2 June 2014) available at http://www.ishr.ch/news (reporting the 7-6 vote by the UN Committee on Non-Governmental Organisations to recommend consultative status to ARC International, a leading NGO working to advance LGBT rights and equality).

${ }^{29}$ Letter of 18 December 2008 from Permanent Representatives of eight States to the President of the GA, UN Doc A/63/3, at 3 (22 December 2008). See Sheill, 'Human Rights, Sexual Orientation, and Gender Identity at the UN General Assembly' (2009) 1(2) Journal of Human Rights Practice 315. The US originally opposed the Statement but changed its position in 2009. See Lau, infra $n 83$.

${ }^{30}$ See Alston and Goodman, supra n 13, 232-3.

${ }^{31}$ See GA Resn 69/182 (18 Dec 2014), UN Doc. A/RES/69/182.

${ }^{32}$ OHCHR Report 2011, supra n 7, para 3, citing a range of Statements, Reports and Guidelines by those organizations.
} 
workers in same-sex marriages or other unions in jurisdictions where they are legal. ${ }^{33}$ In September 2015, in an unprecedented joint initiative, 12 UN agencies issued a joint call to action on ending violence and discrimination against LGBT and intersex adults, adolescents and children. ${ }^{34}$

\section{(b) United Nations Human Rights Council Resolutions and Debates}

The number of references to sexual orientation in reports to the Human Rights Council has steadily increased. There has been also been an increase in the number of States who are willing to discuss human rights issues in terms of sexual orientation discrimination. In 2006, at the Human Rights Council, 54 States submitted a Joint Statement on 'human rights, sexual orientation and gender identity'. ${ }^{35}$ By 2011 a similar Statement entitled 'Ending Acts of Violence and Related Human Rights Violations Based on Sexual Orientation and Gender Identity' was submitted by 85 States. ${ }^{36}$ That Statement had support from every region of the world, including 21 signatories from the Western Hemisphere, 43 from Europe, 5 from Africa and 15 from the Asia/Pacific region. 94 member States of the UN have sponsored a Statement in support of LGBT rights in either the GA, the Human Rights Council, or in both. In June 2011, the Human Rights Council adopted Resolution $17 / 19$ on 'Human rights, sexual orientation and gender identity'. ${ }^{37}$ This was the first specific UN resolution on sexual orientation and gender identity. ${ }^{38}$ The resolution was controversial and was only narrowly passed, by 23 votes to 19 . Those in support were mostly European and Latin American States. The Resolution expressed 'grave concern' at violence and discrimination against individuals based on their sexual orientation and gender identity. It also requested what became the first official United Nations report on

33 'UN Widens Its Same-Sex Marriage Policy To Include All Legally-Married Staff' (8 July 2014) available at http://www.un.org/apps/news/story.asp?NewsID=48222\#.VDfZ-E10yUk. ${ }^{34}$ For the text see http://www.ohchr.org/en/NewsEvents/Pages/DisplayNews.aspx?NewsID=16511\&LangID=E. 35 Joint Statement on Human Rights violations based on sexual orientation and gender identity, UNHRC, 3rd Session (2006), available at Arc International <http://arc-international.net/globaladvocacy/sogi-statements/2006-joint-statement>.

${ }^{36}$ For the text see http://www.state.gov/r/pa/prs/ps/2011/03/158847.htm.

${ }^{37}$ A/HRC/RES/17/19.

${ }^{38}$ There had been references to sexual orientation in resolutions on the death penalty and on arbitrary and summary executions. In 2003 a draft UN Human Rights Commission resolution that contained a general reference to human rights not being hindered on 'the grounds of sexual orientation' was defeated by 24 votes to 22 . 
the issue prepared by the Office of the High Commissioner for Human Rights on Discriminatory Laws and Practices and Acts of Violence Against Individuals based on their Sexual Orientation and Gender Identity. ${ }^{39}$ The Report's findings formed the basis of a Panel discussion that took place at the Human Rights Council in March 2012. ${ }^{40}$ It was remarkable that the Panel discussion was the first time a UN intergovernmental body had held a formal debate on the subject.

However, there was significant opposition to Resolution 17/19. The 19 States which opposed the resolution were Angola, Bahrain, Bangladesh, Cameroon, Djibouti, Gabon, Ghana, Jordan, Malaysia, Maldives, Mauritania, Nigeria, Pakistan, Qatar, Republic of Moldova, Russian Federation, Saudi Arabia, Senegal, and Uganda. Burkina Faso, China, Zambia abstained. The 17 delegates of UN member States in the OIC, ${ }^{41}$ who were members of the Human Rights Council (47 States), walked out of the Palais des Nations in Geneva in protest. ${ }^{42}$ Though it appeared only Muslim delegates walked out, there was reported to be widespread opposition to what is pejoratively described as the 'homosexual agenda' at the UN. ${ }^{43}$ Even within the States that took part in the Panel discussion strong objections were expressed. Pakistan, speaking on behalf of the OIC, stated that it had consistently and firmly opposed the controversial notion of sexual orientation, which was vague and misleading, had no agreed definition and no legal foundation in international law. Licentious behaviour promoted under the concept of sexual orientation was against the fundamental teachings of various religions including but not limited to Islam. Legitimizing homosexuality and other personal sexual behaviours in the name of sexual orientation was unacceptable to the OIC. ${ }^{44}$ Mauritania, speaking on behalf of the Arab Group, opposed any discussion of the subject of sexual orientation. It claimed that debate on the issue would lead to further discord among Member States and undermine the Council's effective response to human rights issues. Attempts to impose the controversial topic of sexual orientation were aimed at creating new rights for specific cultural values which would have negative effects

\footnotetext{
${ }^{39}$ A/HRC/19/41, 17 November 2011.

${ }^{40}$ See Summary of the Discussion, available at http://www.ohchr.org/Documents/Issues/Discrimination/LGBT/SummaryHRC19Panel.pdf. ${ }^{41}$ The OIC represents 57 countries in Africa, Asia and the Middle East.

${ }^{42}$ See Gennarini, 'UN Delegates Walk Out on Sexual Orientation Panel at Human Rights Council' http://www.c-fam.org/fridayfax/volume-15/un-delegates-walk-out-on-sexualorientation-panel-at-human-rights-council.html.

${ }^{43}$ Ibid.

44 'Human Rights Council holds panel discussion on discrimination and violence based on sexual orientation and gender identity' OHCHR Press Release, 7 March 2012.
} 
on existing social structures. ${ }^{45}$ Senegal, on behalf of the majority of the Member States of the African Group, reaffirmed the importance of respecting cultural and religious values when it came to dealing with human rights issues, and rejected any attempt to impose concepts or notions on certain behaviours which did not fall into the internationally agreed set of human rights. ${ }^{46}$ Nigeria, (which in January 2014 enacted a Federal bill banning same-sex marriage and criminalizing homosexual clubs, associations and organizations), argued that other States were seeking to enforce their cultural values abroad. ${ }^{47}$ Of the African States that were on the Human Rights Council in 2011 only South Africa ${ }^{48}$ (significantly a co-sponsor of the Resolution) and Mauritius voted for the resolution. Burkina Faso and Zambia abstained. The remaining African States opposed the resolution.

It was argued that in the absence of universal agreement to require States to recognize sexual orientation and gender identity as prohibited grounds for discrimination, no State should be compelled to do so against its wishes. Any attempt to force through change in this respect would challenge the principles of universality and cultural pluralism and threaten the common ownership of the international human rights programme. ${ }^{49}$ The 1993 Vienna Declaration and Programme of Action of the World Conference on Human Rights was cited to demonstrate the importance of taking into account national and religious particularities in the context of any discussion of human rights and sexual orientation. As is well known, this states: "while the significance of national and regional particularities and various historical, cultural and religious backgrounds must be borne in mind, it is the duty of States, regardless of their political, economic and cultural systems, to promote and protect all human rights and fundamental freedoms.${ }^{50}$ Homosexuality was considered unacceptable to many States because it conflicted with the teachings of various religions and with the cultural and traditional values of many communities. Imposing the concept of sexual orientation would breach the social and cultural rights of communities concerned. ${ }^{51}$ Concern was also expressed that drawing up new documents

\footnotetext{
${ }^{45}$ Ibid.

${ }^{46}$ Ibid.

${ }^{47}$ Ibid. in South Africa see Altman and Symons, supra n 14, 62-7.

${ }^{49}$ Summary, supra n 40, para 19.

${ }^{50} \mathrm{~A} / \mathrm{CONF} .157 / 23$, para 5 .

${ }^{51}$ Summary, supra n 40, para 20.
}

${ }^{48}$ The jurisprudence of the Constitutional Court of South Africa has been notably progressive on issues of sexual orientation discrimination. See National Coalition for Gay and Lesbian Equality v. Minister of Justice (1999) (1) SA 6; Minister of Home Affairs v. Fourie; Lesbian \& Gay Equality Project (2005) ZACC 19; 2006 (1) SA 524. On the complexities of the actual situation 
or agreements that focussed specifically on the rights of LGBT persons was an attempt to create new or special rights and could lead to a splintering of human rights into groups and subgroups. ${ }^{52}$

Despite the strength of the opposition, like-minded States in the UN LGBT Core Group ${ }^{53}$ work strategically to promote the wider recognition of sexual orientation discrimination as part of LGBT rights. No Human Rights Council Resolution was obtained in 2013 because of the opposition of some States. ${ }^{54}$ However, in 2014 the Human Rights Council adopted Resolution $27 / 32$ on 'Human Rights, Sexual Orientation and Gender Identity' by a vote of 25 in favour, ${ }^{55} 14$ against (Algeria, Botswana, Côte d'Ivoire, Ethiopia, Gabon, Indonesia, Kenya, Kuwait, Maldives, Morocco, Pakistan, Russian Federation, Saudi Arabia, and United Arab Emirates) and seven abstentions (Burkina Faso, China, Congo, India, Kazakhstan, Namibia, and Sierra Leone). ${ }^{56}$ The Resolution requested the High Commissioner to update the 2011 report with a view to sharing good practices and ways to overcome violence and discrimination, in application of existing international human rights law and standards. ${ }^{57}$

Within the UN Human Rights Council the debate on sexual orientation discrimination is now being played out by reference to resolutions on 'traditional values' (with which human rights should be consistent) and the 'Protection of the Family'. There is no agreed definition of 'traditional values ${ }^{58}$ but they have been used, for example, to support bans on propaganda in favour of non-traditional sexual relationships in the Russian Federation, in Moldova (repealed in 2013) and in the Ukraine (the Bill was withdrawn in 2015 in the context of EU criticism and deteriorating relations with Russia). In 2012 the Human Rights Council adopted Resolution 21/3, proposed by the Russian Federation, ${ }^{59}$ on Promoting human rights and fundamental

\footnotetext{
${ }^{52}$ Ibid, para 22.

${ }^{53}$ This is a cross regional group that includes 17 states, the European Union, as well as the OHCHR, Human Rights Watch and International Gay and Lesbian Human Rights Commission ${ }^{54}$ See Report of the $24^{\text {th }}$ session of the Human Rights Council, available at http://arcinternational.net/wp-content/uploads/2013/07/HRC24-Report.pdf.

${ }^{55}$ It is notable that the resolution was led by Latin American States (Brazil, Chile, Colombia and Uruguay) and adopted with the support of all five UN regional groups.

56 'Human Rights Council adopts resolution on sexual orientation and gender identity and concludes twenty-seventh session' (26 September 2014), available at http://www.ohchr.org/EN/NewsEvents/Pages/DisplayNews.aspx?NewsID=15109\&LangID=E. ${ }^{57}$ Emphasis added. As of June 2016 no further Resolution had been adopted by the Council. ${ }^{58}$ Article 17(3) AfCHPR provides that 'the promotion and protection of morals and traditional values recognized by the community shall be the duty of the State'.

${ }^{59}$ For critiques of the Russian-sponsored initiative as targeting core tenets of international human rights see UN Human Rights Council: Russia's traditional values initiative result in
} 
freedoms through a better understanding of traditional values of humankind: best practices ${ }^{60} \mathrm{It}$ requested the OHCHR collect information from member States and other relevant stakeholders on best practice in the application of traditional values while promoting and protecting human rights and upholding human dignity, and to submit a summary thereon to the Council. Even that resolution was controversial, being adopted by 25 votes to 15 , with 7 abstentions. The resulting OHCHR Report in $2013^{61}$ noted the divergence of views on whether traditional values provided the basis and background of universal rights and supported their promotion and protection or whether they were misused to justify human rights violations especially with regard to sexual orientation. $^{62}$

As for protection of the family, UN World Conferences in the 1990s and 2000s had been marked by disagreement over references to a diversity of family forms. ${ }^{63}$ In 2014 the Human Rights Council adopted a Resolution on the 'Protection of the family'. ${ }^{64}$ Whereas the resolution did not define 'family', States opposed to the Resolution considered that the reference to a singular 'family' could be used as precedent to oppose rights for same-sex couples, single parents, and other forms of families in future UN negotiations. However, a proposal to add that 'various forms of the family exist' was rejected. ${ }^{65}$ The same process was repeated for a 2015 resolution which enjoyed an increased majority: 29 in favour, 14 against, and 4 abstentions. By contrast, in April 2015 the Human Rights Council's Working Group on Discrimination against

abuse at domestic level (Norwegian Helsinki Committee Policy Paper) http://www.nhc.no/filestore/Publikasjoner/Policy_Paper/NHC_PolicyPaper_5_2014_Traditional values.pdf; Wilkinson, 'Putting "Traditional Values" into Practice: the Rise and Contestation of Anti-Homopropaganda Laws in Russia' (2014) 13 Journal of Human Rights 363.

${ }^{60}$ In 2012 the Advisory Committee to the Human Rights Council prepared a Study on promoting human rights and fundamental freedoms through a better understanding of traditional values of humankind, A/HRC/22/71.

${ }^{61}$ Summary of information from States Members of the United Nations and other relevant stakeholders on best practices in the application of traditional values while promoting and protecting human rights and upholding human dignity (2013). A/HRC/24/22/Corr.1.

${ }^{62}$ Ibid, paras 83-84.

${ }^{63}$ See Saiz,'Bracketing Sexuality: Human Rights and Sexual Orientation - A Decade of Development and Denial at the UN' (2004) 7 Health and Human Rights 48.

${ }^{64}$ Human Rights Council Resolution 26/11 (25 June 2014), 26 in favour, 14 against and six abstentions.

${ }^{65}$ The process was repeated in 2015, see Human Rights Council Resolution 29/22 (29 to 14, with 4 abstentions). See also 'Human Rights Council holds panel discussion on the protection of the family and its members' Press Release, OHCHR, (September 2014). 
Women published a report explicitly including 'families comprising lesbian, gay, bisexual, transgender and intersex (LGBTI) persons' and 'self-created and self-defined families' ${ }^{66}$

\section{(c) UN Human Rights Council - Universal Periodic Review}

The basis for UPR are the UN Charter, the Universal Declaration of Human Rights, the human rights instruments to which a State is party, and voluntary pledges and commitments made by States. ${ }^{67}$ It does not involve new substantive human rights obligations. The UPR processes are more in the nature of dialogic and advisory systems and do not result in a legally binding outcome. The UPR process has been described as offering the 'most useful space' ${ }^{68}$ within the UN system for systematic discussion of sexual orientation issues and for civil society engagement. ${ }^{69}$ Civil society organisations (CSOs), including NGOs, can submit information as stakeholders. Sexual orientation issues have frequently been raised with States during the UPR process. This is not surprising because States can choose which issues to comment on during the interactive dialogue. ${ }^{70}$ More revealing can be the responses to recommendations. In 2008, Benin accepted 33 out of 34 recommendations made during the UPR process. The one exception related to same-sex activities. ${ }^{71}$ As the UPR process has worked through all UN members, many States have openly rejected recommendations to decriminalize homosexuality and legalise samesex marriage or adoption. ${ }^{72}$ However, other States have responded more positively by agreeing

66 'Report of the Working Group on the Issue of Discrimination Against Women in Law and in Practice', UN Doc. A/HRC/29/40 (2 April 2105), para. 23.

${ }^{67}$ Resolution 5/1, Institution-Building of the UN Human Rights Council, Annex I, UPR Mechanism, at A1.

${ }^{68}$ See Karsay, supra n 26, 11-19; Charlesworth and Larking (eds), Human Rights and the Universal Periodic Review (Cambridge: CUP, 2014) 194-6, 219-22.

${ }^{69}$ In June 2015 a 'Civil Society Joint Statement on Sexual Orientation, Gender Identity \& Expression and Intersex Status' at the 29th UN Human Rights Council, on behalf of the International Lesbian and Gay Association and 13 co-sponsoring NGOs, was endorsed by 417 NGO's from more than 105 countries. See http://www.scribd.com/doc/270193193/Civil-SocietyJoint-Statement-on-Sexual-Orientation-Gender-Identity-Expression-and-Intersex-Status-at-the29th-UN-Human-Rights-Council-29-June-201\#scribd.

${ }^{70}$ See for example, Report of the Working Group on the Universal Periodic Review, The former Yugoslav Republic of Macedonia, A/HRC/26/10 (26 March 2014), paras 31, 37, 42, 80, 91, 97, 101.13, 101.38, 101.40-46.

${ }^{71}$ A/HRC/8/L.10/Rev 1 (5 August 2008).

${ }^{72}$ See Report of the $24^{\text {th }}$ session, supra $\mathrm{n}$ 54, Annex I; Cowell and Milon, 'Decriminalisation of Homosexuality through the Universal Periodic Review' (2012) 12 Human Rights Law Review 341. 
to decriminalize or review criminalization. ${ }^{73}$ Recommendations to more effectively investigate allegations of violence against LGBT persons have received a more favourable response. One report suggested that, while the overall acceptance rate for all recommendations in the first cycle of the UPR (2008-2011) was 73\%, acceptance of the recommendations related to recognition of sexual orientation and gender identity (SOGI) related human rights was only $36 \% .{ }^{74}$ From a total of 21,353 recommendations to all States in the first cycle, 493 (2.3\%) referred to sexual orientation and gender identity. Of these 179 (36\%) were 'accepted'. ${ }^{75}$ These 493 recommendations originated from only 39 States. 314 (63.5\%) of those recommendations elicited negative responses in the sense that no meaningful action might be expected. They were either 'rejected', given a 'general response' or received 'no response' at all. Of the 78 countries that criminalise same sex sexual relations, 19 responded to second cycle recommendations. Of these, aside from St Kitts and Nevis that gave a 'General response', the other 18 rejected all recommendations calling for general non-discrimination and 'decriminalisation'. However, 5 of the 18 accepted highly targeted specific recommendations on aspects of sexual orientation discrimination, for example, concerning police violence, education, and impartial investigations. ${ }^{76}$ In 2014, during the second UPR cycle (2012-16), the rules were changed and States can no longer reject recommendations. All recommendations that are not accepted or not responded to are now considered to be 'Noted'. In substance the same pattern as in the first cycle was evident. As of March 2016, 1110 recommendations were made on Sexual Orientation and Gender Identity in the first two UPR cycles. 49 States had raised the issue of and 159 States had received recommendations. However, the majority of recommendations relating to sexual orientation that have been addressed to States that do not recognise LGBT rights have been 'Noted' rather than 'Accepted'. ${ }^{77}$ Thus of the 1100 recommendation, 703 (some $63 \%$ ) have been noted.

\section{(d) UN Special Procedures}

\footnotetext{
${ }^{73}$ Cowell and Milon, ibid at 348-50, discussing Sao Tome and Principe, Seychelles, Palau, Nauru, Mozambique, Samoa, Grenada, St Lucia, and Kiribati.

${ }^{74}$ Itaborahy and Zhu (eds), State Sponsored Homophobia - A World Survey of laws:

Criminalization, Protection and Recognition of Same Sex Love, 9th edn, May 2014, 13, available at http://old.ilga.org/Statehomophobia/ILGA_SSHR_2014_Eng.pdf.

${ }^{75}$ In a positive response to UPR recommendations, Australia introduced federal protections for LGBT people in 2013.

${ }^{76}$ State Sponsored Homophobia 2014, supra n 74, 14-15. ARC International publishes a Report on each HRC Session, see http://arc-international.net/global-advocacy/human-rights-council/.

${ }^{77}$ See UPR Info's Database of UPR recommendations and voluntary pledges, available at http://www.upr-info.org/database/statistics/index_issues.php?fk_issue=47\&cycle=.
} 
The UN Special Procedures processes are also of dialogic and advisory systems. Though interpretations offered may be persuasive and authoritative, the work of the Special Procedures does not result in legally binding outcomes. ${ }^{78}$ Sexual orientation discrimination issues have been increasingly mainstreamed and many of the UN Special Procedure mandate holders have raised these issues within the context of their respective mandates. ${ }^{79}$ The number of references to sexual orientation in their reports to the Human Rights Council and in communications to States by Special Procedures is steadily increasing, although some States have objected to this practice. ${ }^{80}$ However, it is notable that, despite the increasing prominence of the issue, there has never been a proposal for a UN Special Rapporteur on the theme of discrimination based on sexual orientation. There would doubtless be strong political opposition to any such development.

\section{(e) Office of the High Commissioner for Human Rights}

The view of the UN High Commissioner for Human Rights (OHCHR) is that ' $[\mathrm{t}]$ he case for extending the same rights to lesbian, gay, bisexual and transgender (LGBT) ${ }^{81}$ persons as those enjoyed by everyone else is neither radical nor complicated. It rests on two fundamental principles that underpin international human rights law: equality and non-discrimination' ${ }^{82}$ States and international organizations that support sexual orientation discrimination as a human right tend to follow this universal or equal human rights approach. ${ }^{83}$ The UN SG has stated that, 'Where there is tension between cultural attitudes and universal human rights, universal human rights must carry the day'. ${ }^{84}$ In his message to the Oslo Conference on Human Rights, Sexual Orientation and Gender Identity he commented that:

\footnotetext{
${ }^{78}$ See Limon and Piccone, U.N. Human Rights Experts: Determinants of Influence (Brookings Institute, 2014) available at http://www.brookings.edu/.

${ }^{79}$ See Report of Special Rapporteur on Freedom of Religion or Belief on violence committed in the name of religion, UN Doc A/HRC/28/66 (29 December 2014), paras. 11, 34, 42; OHCHR Report 2011, supra n 7; International Commission of Jurists, Sexual Orientation and Gender Identity in Human Rights Law: References to Jurisprudence and Doctrine of the UN Human Rights System (5th ed. 2013), available at http://icj.wpengine.netdna-cdn.com/wpcontent/uploads/2013/06/SOGI-UN-Compil_electronic-version.pdf.

${ }^{80}$ See, for example, Report of the $24^{\text {th }}$ session of the Human Rights Council, Annex II, available at http://arc-international.net/wp-content/uploads/2013/07/HRC24-Report.pdf

${ }^{81}$ Increasing use of 'LGBTI' signifies the addition of intersex persons.

${ }^{82}$ OHCHR Report 2011, supra $\mathrm{n} 7$ at 7.

${ }^{83}$ See Lau, 'Sexual Orientation: Testing the Universality of International Human Rights Law' (2004) 71 University of Chicago Law Review 1689.

${ }^{84}$ Oslo Conference Report, supra n 6.
} 
Some will oppose change. They may invoke culture, tradition or religion to defend the status quo. Such arguments have been used to try to justify slavery, child marriage, rape in marriage and female genital mutilation. I respect culture, tradition and religion - but they can never justify the denial of basic rights. ${ }^{85}$

Applying the approach that sexual orientation issues are covered by existing rights, the 2012 OHCHR Report, Born Free and Equal - Sexual Orientation and Gender Identity in International Human Rights Law, sets out five core obligations of States with respect to protecting the human rights of LGBT persons, ${ }^{86}$ including: to protect individuals from homophobic and transphobic violence; to prevent torture and cruel, inhuman and degrading treatment of LGBT persons; to decriminalize homosexuality; to prohibit discrimination based on sexual orientation and gender identity, and to respect freedom of expression, association and peaceful assembly. On 26 July 2013, UN High Commissioner for Human Rights launched a year-long public information campaign, based on the 2012 OHCHR Report, designed to raise awareness of homophobic and transphobic violence and discrimination and promote greater respect for the rights of LGBT people everywhere ${ }^{87}$ However, at the Human Rights Council's 24th session in 2013, Pakistan, speaking on behalf of the OIC, said the OIC had consistently raised its reservations about 'controversial' notions that had not been universally agreed, such as LGBT rights, and therefore could not support any initiative by the High Commissioner in this respect. Iran also had strong reservations about any education campaign on lesbian, gay, bisexual and transgender people supported by the High Commissioner on the basis that it would contradict established human rights principles. Saudi Arabia stated that the rights of LGBT people were against Islamic Sharia. ${ }^{88}$ Similar statements were made by Qatar, Pakistan, Saudi Arabia and Nigeria at the 29th session of the HR Council in 2015 after the presentation of the High Commissioner's updated Report on human rights violations based on sexual orientation and gender identity.

\footnotetext{
${ }^{85}$ UN SG, 'Message to The Oslo Conference' supra n 6, 32.

${ }^{86}$ See OHCHR Report 2012, supra n 15.

${ }^{87}$ See Press Release, 'UN Human Rights Office Launches Unprecedented Global Campaign for Lesbian, Gay, Bisexual and Transgender Equality (26 July 2013) available at http://www.prweb. com/releases/2013/7/prweb10967571.htm. The initiative seems to have come from the OHCHR. ${ }^{88}$ For another context see Osborne, 'Saudi Arabia insists UN keeps LGBT rights out of its development goals', The Independent, 29 September 2015. This interpretation of Sharia is contested by Rehman and Polymenopoulou, 'Is Green Part of the Rainbow? Sharia, Homosexuality, and LGBT Rights in the Muslim World' (2013) Fordham International Law Journal 1; Hamzic, 'The Case of "Queer Muslims"' (2011) 11 Human Rights Law Review 237.
} 


\section{(f) The Human Rights Committee and the other UN Treaty Bodies}

None of the UN human rights treaties contain any express reference to sexual orientation. The interpretation of those treaties is of critical importance for the large numbers of States parties that have consented to be bound by those treaties. ${ }^{89}$ Both States and UN treaty bodies consider that they have authority to interpret treaties but there is no clearly established rule on which has the superior authority. ${ }^{90}$ With respect to the ICCPR, the General Comments and Concluding Observations of the Human Rights Committee (HRC), and their Views under the First Optional Protocol, are not legally binding but their interpretations are regarded as authoritative both by States parties and the HRC itself. ${ }^{91}$ The same is broadly true for all of the UN treaty bodies. ${ }^{92}$ Nonetheless, it has been suggested that it is through the mechanism of treaty interpretation by the treaty bodies that the some of the 'strongest existing explicit protections against discrimination on the basis of sexual orientation' have been achieved at the UN. ${ }^{93}$ Some of the earliest and leading Treaty Body jurisprudence was developed by the HRC under the ICCPR. ${ }^{94}$ The HRC interprets the ICCPR on the basis that it is a 'living instrument', to be interpreted in accordance with its object and purpose. ${ }^{95}$ However, it does not make any express reference to the relevance of State consensus and has explicitly rejected the idea of affording States a margin of appreciation in the implementation of the ICCPR. ${ }^{96}$ In a landmark decision in Toonen $v$.

Australia in 1994 the HRC interpreted 'sex' in Articles 2(1) and 26 of the ICCPR as covering 'sexual orientation' and thus States parties are obliged to protect individuals from discrimination

${ }^{89}$ See Sexual Orientation and Gender Identity in Human Rights Law, supra n 79, 30-123.

${ }^{90}$ See Mechlem, 'Treaty Bodies and the Interpretation of Human Rights' (2009) 42 Vanderbilt Journal of Transnational Law 905 at 908 (noting the differences between courts and UN treaty bodies).

${ }^{91}$ See Tyagi, The UN Human Rights Committee (Cambridge: CUP, 2011) 43-4; HRC, General Comment 33, The Obligations of States Parties Under the Optional Protocol to the ICCPR, (2008).

${ }^{92}$ Some of them are more focussed on progressive obligations and the policies and strategies adopted by States, rather than having the HRC's strongly legalistic focus. See generally Keller and Ulfstein (eds), UN Human Rights Treaty Bodies: Law and Legitimacy (Cambridge: CUP, 2012).

${ }^{93}$ See Kukura, 'Sexual Orientation and Non-Discrimination' (2005) 17 Peace Review 181 at 183.

94168 States parties as of March 2016.

${ }^{95}$ See GC 31 (2004), The Nature of the General Legal Obligation Imposed on States Parties to the Covenant; Judge v. Canada, Cmn No. 829/1998, para 10.3.

${ }^{96}$ Länsman et al. v. Finland, Cmn No. 511/1992, para 9.4; GC 34, para 16 (on Freedom of Expression in Article 19 ICCPR, UN Doc. CCPR/C/GC/34 (12 September 2011). For the ECtHR the absence of consensus would normally lead to States being afforded a wide margin of appreciation. 
on the basis of their sexual orientation. ${ }^{97}$ The HRC offered no explanation or justification for its interpretation. There was no reference to the drafting history (travaux preparatoires) (even though Australia had referred to it), State practice, other human rights treaties, national legislation, or any other evidence of State practice. Subsequently the HRC has not sought to distinguish its decision in the Toonen case on the basis of the particular moral and social situation then obtaining in Australia. Rather its established jurisprudence is that the criminalisation of consensual adult same-sex relations violates Article 17 of the ICCPR (right to privacy).$^{98}$ Thus the HRC did not accept that, for the purposes of Article 17, moral issues were exclusively a matter of domestic concern. ${ }^{99}$ Of course, States which criminalize same-sex relationships would not accept the HRC's interpretation that such relationships are part of the right to privacy in Article 17. ${ }^{100}$ For example, the representative from Botswana informed the HRC that it viewed same-sex sexual activity as immoral contra bonos mores which the nation traditionally held as contrary to traditional and religious beliefs. ${ }^{101}$ Although it had specifically been asked by Australia for guidance on whether 'sexual orientation' came within 'other status' the HRC did not answer the point. However, in Concluding Observations that refer to the criminalization of same-sex sexual activities between consenting adults it commonly includes reference to both Articles 17 and $26 .{ }^{102}$ Significantly though, the other UN human rights treaty bodies have proceeded on the basis that 'sexual orientation' does come within 'other status'. ${ }^{103}$

\footnotetext{
${ }^{97}$ Cmn No. 488/1992, para 8.7. See Joseph, 'Gay Rights Under the ICCPR - Commentary on Toonen v. Australia' (1994) 13 Univ Tasmania Law Review 392; Helfer and Miller, 'Sexual Orientation and Human Rights' (1996) 9 Harvard Human Rights Journal 61. The UN Human Rights Council's Working Group on Arbitrary Detention regularly cites Toonen in finding the detention of homosexuals to be arbitrary.

${ }^{98}$ The HRC has also noted that laws criminalizing homosexuality run counter to the implementation of effective education programmes in respect of HIV/AIDS prevention, see CCPR/C/JAM/CO/3 (HRC, 2011), para 9 (Jamaica). The CeeESCR has observed that 'By virtue of Article 2(2) and Article 3, the Covenant proscribes any discrimination in access to health care and underlying determinants of health, as well as to means and entitlements for their procurement, on the grounds of... sexual orientation...'; GC 14, para 18 (2000) on the right to the highest attainable standard of health.

${ }^{99}$ Toonen, supra $\mathrm{n} 97$, para 8.6.

${ }^{100} \mathrm{Cf}$ the difference of opinion in the UK Supreme Court on whether private life extends to photographs of a child's participation in criminal riots see In the matter of an application by JR38 for Judicial Review (Northern Ireland) (2015) UKSC 42.

${ }^{101}$ See UN Doc CCPR/C/SR 2515, para 12.

${ }^{102}$ See CCPR/C/BWA/CO/1, para 22 (Botswana) (2008).

${ }^{103}$ See, for example, Committee on Economic, Social and Cultural Rights (CeeESCR), GC 20, para 32 on 'Non-Discrimination in Economic, Social and Cultural Rights' (2009).
} 
As is well known, the HRC has interpreted Article 26 ICCPR as a general, free-standing, equality and non-discrimination guarantee which prohibits discrimination in law or in fact in any field regulated and protected by public authorities. ${ }^{104}$ This is of crucial importance in this context because it means that discrimination based on sexual orientation could be a violation of Article 26 irrespective of whether the issue concerned is within any other ICCPR rights, such as privacy or family life. Thus its scope extends to the enjoyment of economic, social and cultural rights and the HRC has indeed found violations of Article 26 on the basis of discrimination on the ground of sexual orientation in relation to such rights. In Young v Australia, ${ }^{105}$ decided in 2003, and $X v$ Colombia ${ }^{106}$ decided in 2007, the HRC concluded that differences in treatment in the award of pension benefits to a same-sex partner were a violation of the right to be free from discrimination 'on grounds of sex or sexual orientation.' In neither case had the State concerned put forward an argument that the differences were reasonable and objective. ${ }^{107}$ States that disagree with the inclusions of sexual orientation as within 'sex' or 'other status' would not accept the HRC's interpretation. Alternatively they would maintain that the distinctions they draw on that basis are reasonable and objective.

The HRC has taken a wide interpretation of the concept of a 'family', acknowledging the existence of various forms of family, such as unmarried couples and their children or single parents and their children. ${ }^{108}$ If a group of persons is regarded as a family under the legislation and practice of a State, it must be given the protection provided for by Article 23 ICCPR. The HRC has not expressly determined whether same-sex couples can establish a family life. ${ }^{109}$ Of course, States which do not accept that same-sex couples can constitute a family would not agree with such an interpretation in any event. They would also support the interpretation of the HRC in Joslin v New Zealand in 2002 which held that States were not required, under the ICCPR, to allow same-sex couples to marry. ${ }^{110}$ Although the State party made repeated references to the travaux preparatoires and academic studies, the HRC's analysis solely focussed on what it

\footnotetext{
${ }^{104}$ Broeks v. Netherlands, Cmn No. 172/1984, para 12.1; HRC, GC 18, para 12; Joseph et al (eds), The ICCPR - Cases, Materials and Commentary, 3rd edn (Oxford: OUP, 2013) 759-831. ${ }^{105}$ Cmn No. 941/2000, para 10.4 .

${ }^{106}$ Cmn No. 1361/2005, para 9.

107 The decisions were ultimately implemented by legislative provisions in Australia and by a subsequent Constitutional Court decision in Colombia respectively. In that sense the HRC's decisions created new advocacy opportunities at a domestic level

${ }^{108}$ GC 19, para 2.

${ }^{109}$ In $X$ v. Colombia, Cmn No. 1361/2005, two individual members argued that they could not do so.

${ }^{110}$ Cmn No. 902/1999, para 8.2. At that time only one State in the world, the Netherlands, allowed same-sex couples to marry. New Zealand legislated for same-sex marriage in 2013.
} 
considered to be the intentions of the States parties, as expressed by the text, rather than a purposive or teleological approach. It explained that Article 23(2) ICCPR was the only substantive provision in the Covenant which defined a right by using the term 'men and women', rather than 'every human being', 'everyone' and 'all persons'. Use of the term 'men and women, rather than the general terms used elsewhere in Part III of the Covenant, has been consistently and uniformly understood as indicating that the treaty obligation of States parties stemming from Article 23(2) is to recognize as marriage only the union between a man and a woman wishing to marry each other.' 111 Two members of the HRC took the view that there could be circumstances, for example, concerning differences in benefits, where the consequences of preclusion from marriage could constitute discrimination. ${ }^{112}$

HRC jurisprudence has been strict in its assessment of what constitutes reasonable and objective grounds for restrictions on rights based on sexual orientation. In October 2012, in Fedotova v. Russian Federation, ${ }^{113}$ the HRC considered that the State had not shown that a restriction on the right to freedom of expression in relation to 'propaganda of homosexuality' as opposed to propaganda of heterosexuality or sexuality generally - among minors was based on reasonable and objective criteria. Moreover, no evidence that would point to the existence of factors justifying such a distinction has been advanced. ${ }^{114}$ Furthermore, the HRC was of the view that, by displaying posters that declared 'Homosexuality is normal' and 'I am proud of my homosexuality' near a secondary school building, F had not made any public actions aimed at involving minors in any particular sexual activity or at advocating for any particular sexual orientation. Instead, she was giving expression to her sexual identity and seeking understanding for it. ${ }^{115}$ While the HRC recognized the role of the State authorities in protecting the welfare of minors, it observed that the State failed to demonstrate why on the facts of the present communication it was necessary, for one of the legitimate purposes of Article 19(3) ICCPR (freedom of expression) to restrict the author's right to freedom of expression for expressing her sexual identity and seeking understanding for it, even if indeed, as argued by the State, she intended to engage children in the discussion of issues related to homosexuality. Accordingly, the HRC concluded that F's conviction of an administrative offence for 'propaganda of homosexuality among minors' on the basis of the ambiguous and discriminatory section of the

\footnotetext{
${ }^{111}$ Ibid.

112 Individual Opinion of Lallah and Scheinin.

${ }^{113}$ Cmn No. 1932/2010, (2012).

${ }^{114}$ Fedotova, para 10.6, citing Young v. Australia, supra n 105, para 10.4; and X. v. Colombia, supra n 106, para 7.2.

${ }^{115}$ Fedotova, para 10.7.
} 
Ryazan Region Law, amounted to a violation of her rights under Article 19(2), read in conjunction with Article 26 (equality and non-discrimination). ${ }^{116}$

Whilst the HRC has developed some of the most legally significant jurisprudence on these issues, it has also been criticised on the basis that its practice in raising sexual orientation issues has been inconsistent. ${ }^{117}$ Issues have been raised with some States but not others. Until 2014, none of its General Comments had ever expressly referred to LGBT issues. The 2014 General Comment on Article 9: Liberty and Security of Person, ${ }^{118}$ was the first to state that 'Everyone' includes, among others, 'lesbian, gay, bisexual and transgender persons'. ${ }^{119}$ It referred to 'violence against persons on the basis of their sexual orientation or gender identity' 120 and to arrest and detention on discriminatory grounds based on sexual orientation. ${ }^{121}$

This section has focussed on the HRC but all of the UN human rights treaty bodies now raise sexual orientation issues on a regular basis. ${ }^{122}$ The Committee Against Torture, the Economic, Social and Cultural Rights Committee, the Committee on the Elimination of Discrimination Against Women and the Committee on the Rights of the Child have all adopted GC's on LGBT rights. ${ }^{123}$

(g) The Yogyakarta Principles

${ }^{116}$ Fedotova, para 10.8. In 1982 in Hertzberg v. Finland, Cmn No. 14/1979, the HRC had upheld restrictions on freedom of expression relating to the encouragement to indecent behaviour between members of the same sex.

${ }^{117}$ See Gerber and Gory, 'The UN Human Rights Committee and LGBT Rights: What Is It Doing? What Could It Be Doing?’ (2014) 14 Human Rights Law Review 403.

118 GC 35, pr. 7 (28 October 2014).

${ }^{119}$ Ibid, para. 3.

${ }^{120}$ Ibid, para 7.

${ }^{121}$ Ibid, para 17.

${ }^{122}$ See, for example, CO's of HRC on Mexico (CCPR/C/MEX/CO/5), para 21, and Uzbekistan (CCPR/C/UZB/CO/3), para 22; CRC Cee, GC 4 para 6 (2003), GC 13 (2011), para 74; CAT Cee, GC 2, paras 20, 21; CEDAW Cee, GR 27, para 13; GR 28 para 18, GR 29 para 24; CEDAW/C/SGP/CO/4, para 22 (Senegal); Cee ESCR, GC 22 (2016) on the right to sexual and reproductive health, paras 9, 19, 23 and 30. A search of the OHCHR's Universal Human Rights Index in March 2016 for 'sexual orientation' found 705 results. In November 2015 the CAT Cee held that the refoulement of an LGBT human rights defender would breach the Convention Against Torture, JK v. Canada, Cmn No. 562/2013, UN Doc CAT/C/56/D/562/2013.

${ }^{123}$ Roseman and Miller, supra n 9, comment that the 'ideal functional response to the ad hoc aspect of the treaty body jurisprudence could be a joint general comment across the treaty bodies on sexual rights' but conclude that this outcome is unlikely because of the current fragmented system, at 373 . 
An enormous range of lesbian, gay, bi-sexual and transgender (LGBT) initiatives have been undertaken in regional and international governmental organisations. ${ }^{124}$ In 1995, although express references to sexual orientation were ultimately deleted from the Declaration and Platform for Action of the Fourth World Conference on Women, the issues were placed on the international agenda. ${ }^{125} 2006$ saw the adoption by a distinguished group of international human rights experts of the Yogyakarta Principles on the Application of International Human Rights Law in relation to Sexual Orientation and Gender Identity. ${ }^{126}$ These are not a UN instrument but are considered here for convenience because of their intended effect namely to apply existing international human rights law standards to address the situation of LGBT people, and issues of intersexuality. The OHCHR, UN Special Procedures, UN Human Rights Treaty Bodies and the Council of Europe Commissioner for human rights have referenced the Yogyakarta Principles. Again though there has been opposition from some States. In 2010, the UN Special Rapporteur on the Right to Education presented an interim report on the human right to comprehensive sexual education to the UNGA, in which he cited the Yogyakarta Principles as a human rights standard. In the ensuing discussion, the majority of members of the Third Committee of the GA recommended against adopting a reference to the Yogyakarta Principles. ${ }^{127}$ A reference to the Principles as a source of international law in a section of the Report of the Special Rapporteur on the Promotion and Protection of Human Rights and Fundamental Freedoms while Countering Terrorism ${ }^{128}$ was criticised in the Third Committee of the GA as inappropriate by Tanzania on behalf of the African Group, and by St Lucia and Malaysia on behalf of the OIC. ${ }^{129}$ Unusually the voting in the Third Committee on the resolution

124 There are an enormous number of very active LGBT NGOs nationally, regionally and internationally. The International Lesbian, Gay, Bisexual, Trans and Intersex Association is an international organization, with a HQ in Geneva, which bring together more than 1100 LGBT groups from 110 countries, see http://ilga.org. See also Thorenson, Transnational LGBT Activism (Minneapolis: University of Minnesota Press, 2014).

${ }^{125}$ See Helfer and Miller, supra $n 97$.

${ }^{126}$ See O'Flaherty and Fisher, 'Sexual Orientation, Gender Identity and International Human Rights Law: Contextualising the Yogyakarta Principles' (2008) 8 Human Rights Law Review 207; Brown 'Make Room for Sexual Orientation and Gender Identity in International Human Rights Law' (2010) 31 Michigan Journal of International Law 821.

${ }^{127}$ See 'General Assembly, Human Rights Council Texts...', Press Release, 65th GA, GA/SHC/3987 (25 October 2010), available at http://www.un.org/press/en/2010/gashc3987.doc.htm.

${ }^{128}$ UN Doc A/64/211, para 48, n 16 (3 August 2009)

${ }^{129}$ See Ettelbrick and Zerán, The Impact of the Yogyakarta Principles on International Human Rights Law Development, available at http://www.ypinaction.org/files/02/57/Yogyakarta_Principles_Impact_Tracking_Report.pdf at 15. 
on Protecting Human Rights While Countering Terrorism was extremely divisive. Its approval was secured only after two amendments related to the approach to sexual orientation and gender issues were agreed. ${ }^{130}$

\section{Developments within Regional Human Rights Systems}

This Part examines the major developments in the regional human rights systems and organizations. Again, the key purpose is to ascertain the degree to which sexual orientation issues have or have not been addressed as within existing law and by existing human rights mechanisms and institutions.

(a) The Council of Europe - Reports and International Instruments

The Council of Europe (CoE), with 47 member States and covering over 820 million persons, has taken a leading role in the fight against discrimination on the grounds of sexual orientation. ${ }^{131}$ Its admissions criteria, standards and mechanisms seek to promote and ensure respect for the human rights of every individual. These include equal rights and dignity of all human beings, including lesbian, gay, and bisexual persons. ${ }^{132}$ The first CoE treaty explicitly referring to non-discrimination on grounds of sexual orientation was the 2007 Convention on the Protection of Children against Sexual Exploitation and Sexual Abuse. ${ }^{133}$ The 2011 Convention on Preventing and Combating Violence against Women and Domestic Violence was the first to refer to non-discrimination on grounds both sexual orientation and gender identity. ${ }^{134}$ In 2010 the Committee of Ministers of the CoE adopted a Recommendation to member States on measures to combat discrimination on grounds of sexual orientation or gender identity. ${ }^{135}$ Over

${ }^{130}$ See 'Girl Child, Eliminating Racism, Protecting Human Rights while Countering Terrorism among Issues...' http://www.un.org/press/en/2009/gashc3970.doc.htm; A/C.3/69/SR.26. See Otto, 'Transnational Homo-Assemblages: Reading 'Gender' in Counter-terrorism Discourses' (2013) 4 Jindal Global Law Review 79.

${ }^{131}$ See Council of Europe, Committee of Equality and Non-discrimination, Report on Tackling discrimination on the grounds of sexual orientation and gender identity, 7 June 2013, available at http://assembly.coe.int/ASP/Doc/XrefViewPDF.asp?FileID=19779\&Language=en.

${ }^{132}$ See 'Combating discrimination on the grounds of sexual orientation or gender identity' Council of Europe, available at http://www.coe.int/t/dg4/lgbt/default_en.asp

${ }^{133}$ Article 2, Lanzarote Convention, CETS No. 201.

${ }^{134}$ Istanbul Convention, CETS No. 210.

${ }^{135}$ Recommendation CM/Rec(2010)5, available at https://wcd.coe.int/ViewDoc.jsp?id=1606669. See also Resolutions 1728 (2010) and 1915 
100 pages of standards have been adopted within the framework of CoE's institutions. ${ }^{136}$ In 2011 the Council of Europe's then Commissioner for Human Rights, Thomas Hammarberg, published a report entitled Discrimination on grounds of sexual orientation and gender identity in

Europe. ${ }^{137}$ This was the largest study ever made on homophobia, transphobia and discrimination on grounds of sexual orientation and gender identity in the 47 member States of the CoE. One of the aims was to provide objective data and information that would facilitate a well-informed discussion with national authorities. The majority of member States (38) have recognised that sexual orientation can be a ground of discrimination in their comprehensive or sectoral nondiscrimination legislation. At that time, nine member States did not appear to protect LGB persons against discrimination. However, the issue of sexual orientation discrimination is still politically divisive and sensitive amongst CoE member States such as the Russian Federation, Moldova, the Ukraine, Lithuania, Croatia, Serbia, Slovakia, Slovenia and Switzerland.

\section{(b) The Council of Europe - The European Convention on Human Rights}

Of all the regional and international human rights systems it is the developments in the ECHR with respect to sexual orientation discrimination that have been the most remarkable. As is well known the ECtHR interprets the ECHR as a 'living instrument' and the rights in it are intended to be practical and effective. The ECtHR has developed the doctrine of affording States a margin of appreciation ${ }^{138}$ and in ascertaining the breadth of this margin the ECtHR looks to the existence or otherwise of member State consensus on the issue concerned. ${ }^{139}$ The most significant ECtHR decisions on sexual orientation issues have only been given since 1981 and national implementation of some key elements of the jurisprudence has taken decades. Between 1955 and 1980 a number of applications challenging the criminalization of homosexuality were declared inadmissible by the European Commission on Human Rights on the basis that there was

(2010) of the Parliamentary Assembly. The Council of Europe has an Expert Committee on Discrimination on Grounds of Sexual Orientation and Gender Identity.

${ }^{136}$ Combating Discrimination on grounds of sexual orientation or gender identity - Council of Europe Standards (2011) available at http://www.coe.int/t/dghl/standardsetting/hrpolicy/Publications/LGBT_en.pdf

${ }_{137}$ Available at https://www.coe.int/t/commissioner/Source/LGBT/LGBTStudy2011_en.pdf.

${ }^{138}$ Protocol 15 ECHR (not yet in force) will insert a reference to the margin of appreciation into the Preamble to the ECHR.

${ }^{139}$ See McGoldrick, 'An Argument for the Universal Application of the Margin of Appreciation by the Human Rights Committee’ (2016) 65 ICLQ 21. 
no violation of any ECHR right. ${ }^{140}$ In 1977 an application against the UK was held admissible but was disposed of by the Committee of Ministers. ${ }^{141}$ Not until 1981 did a case reach the ECtHR. Remarkably, the application was successful. In Dudgeon v. United Kingdom ${ }^{142}$ the ECtHR held, by 15 votes to $4,{ }^{143}$ that the criminal prohibition on private homosexual conduct between consenting adults in Northern Ireland interfered with their right to respect for private life under Article 8 ECHR. That jurisprudence was subsequently applied to Ireland in $1988^{144}$ and to Cyprus in 1993. ${ }^{145}$ The mere existence of such legislation violated Article $8 .{ }^{146}$ Although most States had decriminalised adult homosexuality by 1998, it took until February 2014, which is some 33 years after Dudgeon, for its abolition in all ECHR territories. ${ }^{147}$

Dudgeon was seminal because it squarely placed homosexual activity within private life under Article 8 ECHR. ${ }^{148}$ However, as in that case, the ECtHR practice was to decline to consider a non-discrimination claim under Article 14 separately even when the issue concerned overtly discriminatory policies. ${ }^{149}$ It would only consider Article 14 separately if it was considered to constitute a fundamental aspect of the case. In contrast with Article 26 ICCPR, ${ }^{150}$ the non-discrimination guarantee in Article 14 ECHR is an accessory right. Even if there is no violation of an ECHR right there may be a violation of Article 14 if the claim falls within the

${ }^{140}$ See, for example, W.B. v. Germany, A. 104/55, 17 December 1955.

${ }^{141} X v . U K$, A. $7215 / 75,7$ July 1977 , available at http://hudoc.echr.coe.int/sites/eng/pages/search.aspx?i=001-74369.

${ }^{142}$ Dudgeon v. UK, A. 7525/76, (1982) 4 EHRR 40. Sanders, supra n 27, comments that, 'Privacy is obviously an inadequate basis for constructing a broader regime of equality for homosexuals, because heterosexual relationships are publicly recognised, socially and legally, in all societies', at n 46 .

${ }^{143}$ The Cypriot Judge noted in dissent that Christian and Moslem religions were all united in the condemnation of homosexual relations and of sodomy.

${ }^{144}$ Norris v. Ireland, A. 10581/83, (1991) 3 EHRR 186, para 46.

${ }^{145}$ See Modinos v. Cyprus, A. 15079/89. (1993) 16 EHRR 485. Cyprus argued there was no interference but did not seek to justify any such interference.

${ }^{146}$ Similarly in A.D.T. v. UK, A. 35765/97, (2001) 31 EHRR 33.

147 The last territory to abolish such criminal offences was Turkish Republic of Northern Cyprus. H. C. v. Turkey, A. 6428/12, was struck out a as the applicant wished to withdraw the application in the light of the legislative amendment.

${ }^{148}$ Dudgeon was cited in the majority opinion in the US Supreme Court in Lawrence v. Texas 538 US 58 (2003) (intimate consensual sexual conduct part of the liberty protected by substantive due process under the Fourteenth Amendment). Notwithstanding, the relevant laws remain on the books in many States. See Yoshino, 'The New Equal Protection' (2011) 124 Harvard Law Review 747 at 776-81.

${ }^{149}$ See, for example, in Smith and Grady v UK, A. 33985/96 and 33986/96, (2000) 29 EHRR 493 (the investigation into and subsequent discharge of personnel from the Royal Navy on the basis they were homosexual was a breach of their right to a private life).

${ }^{150}$ Protocol 12 ECHR brings Article 14 ECHR closer to Article 26 ICCPR but, as of January 2016 , it had only been ratified by 19 States. 
'ambit' of an ECHR right. ${ }^{151}$ On the basis of the crucial jurisprudential developments on sexual orientation aspects of Article 8 ECHR it has now become easier to construct Article 14 complaints of discrimination based on sexual orientation. These complaints have been considered to come within the prohibition of discrimination on grounds of 'sex' or 'other status'. ${ }^{152}$ In Alekseyev v. Russia ${ }^{153}$ in 2010 the ECtHR observed that particularly weighty reasons needed to be advanced to justify the measure complained of when a distinction based on sexual orientation, operated in the 'intimate and vulnerable sphere of an individual's private life'. ${ }^{154}$ The ECtHR has increasingly rejected the justifications proffered for differentiations in national law. ${ }^{155}$ The ECtHR now considers discrimination based on sexual orientation to be as serious as discrimination based on 'race, origin or colour' 156 and as being in the same suspect class as discrimination based on sex. ${ }^{157}$ In its 2013 judgment in $X v$. Austria ${ }^{158}$ the Grand Chamber stated that:
Sexual orientation is a concept covered by Article 14. The Court has repeatedly held that, just like differences based on sex, differences based on sexual orientation require particularly serious reasons by way of justification or, as is sometimes said, particularly convincing and weighty reasons... Where a difference of treatment is based on sex or sexual orientation the State's margin of appreciation is narrow... Differences based solely on considerations of sexual orientation are unacceptable under the Convention ${ }^{159} \ldots$

\footnotetext{
${ }^{151}$ See Harris et al, Law of the European Convention on Human Rights, $3^{\text {rd }}$ edn (Oxford: OUP, 2014) at 781-22.

${ }^{152}$ Sutherland v. UK, A. 25186/94, European Commission, (1997) 24 EHRR CD22; Salgueiro Da Silva Mouta v. Portugal, (2001) 31 EHRR 47.

${ }^{153}$ A. 4916/07, 25924/08 and 14599/09 (2010).

${ }^{154}$ Ibid, pr. 108 (emphasis added). On vulnerability see Peroni and Timmer, 'Vulnerable Groups: The Promise of an Emerging Concept in ECHR Law' (2013) 11 International Journal of Constitutional Law 1056.

${ }^{155}$ It has rejected justifications for differential ages of consent for heterosexual, homosexual and lesbian relations L. and V. v. Austria, A. 39392/98 and 39829/98, (2003) 36 EHRR 55, and for refusal to delete the criminal record of homosexuals convicted under discriminatory age of consent laws, E.B. and others v. Austria, A. 31913/07 and others.

${ }^{156}$ Vejdeland and Other v. Sweden, A. 1813/07, (2014) 58 EHRR 15, para 55.

${ }^{157}$ Karner v. Austria, A. 40016/98, (2004) 38 EHRR 24. For a critique of the suspect class doctrine see Bedi, Beyond Race, Sex, and Sexual Orientation (Cambridge: CUP, 2013).

${ }^{158}$ A. 19010/07, (2013) 57 EHRR 14.

${ }^{159}$ Ibid, para 99 (citations omitted).
} 
Thus under the ECHR, in US terminology, discrimination on grounds of sexual orientation is presumptively treated as 'suspect'. ${ }^{160}$

There have been major jurisprudential developments in relation to many ECHR provisions with respect to sexual orientation. Most of them have only occurred since 1999 and rely heavily on the idea of the ECHR as a 'living instrument' ${ }^{161}$ As of 2016 there have been over 50 sexual orientation cases where a violation of the ECHR has been found and the number is steadily rising. ${ }^{162}$ Some of the most significant have concerned discriminatory rules concerning contact rights, ${ }^{163}$ the adoption of children, ${ }^{164}$ second-parent adoption of children, ${ }^{165}$ rules on child maintenance, ${ }^{166}$ succession rights, ${ }^{167}$ freedom of expression and assembly by

\footnotetext{
${ }^{160}$ On the US Supreme Court's standard of scrutiny for measures that discriminate on grounds of sexual orientation see Laird, 'The Questions Raised by Striking Down DOMA', available at http://ohrh.law.ox.ac.uk/the-questions-raised-by-striking-down-doma/.

${ }^{161}$ See Sexual orientation issues, ECtHR, Factsheet, available at http://www.echr.coe.int/Documents/FS_Sexual_orientation_ENG.pdf (February 2016).

${ }^{162}$ See generally Johnson, Homosexuality and the European Court of Human Rights (Abingdon: Routledge, 2012).

163 Salgueiro Da Silva Mouta v. Portugal, A. 33290/96, (2001) 31 EHRR 47.

${ }^{164}$ E.B. v. France, A. 43546/02, (2008) 47 EHRR 21 (Grand Chamber). Effectively reversing Frette v. France, 36515/97, (2002) 38 EHRR 438.

${ }^{165}$ X v. Austria, A. 19010/07, (2013) 57 EHRR 14. Distinguishing Gas and Dubois v. France, A. 25951/07, 15 March 2012. There was a strong dissent by seven members. In their view the majority had gone beyond the usual limits of the 'living instrument' approach to interpretation. The dissent was based on the particular facts of the case combined with the content of the Austrian legislation and a number of considerations relating to comparative and international law. See Johnson, 'Adoption, Homosexuality and the European Convention on Human Rights: Gas and Dubois v France' (2012) 75 MLR 1136.

166 J.M. v. United Kingdom, A. 37060/06, (2011) 53 EHRR 6.

${ }^{167}$ Karner v. Austria, A. 40016/98, (2003) 38 EHRR 528.
} 
organizations supporting LGBT rights, ${ }^{168}$ treatment in detention ${ }^{169}$ and the obtaining of a residence permit for family reunification. ${ }^{170}$

In Schalk and Kopf v. Austria ${ }^{171}$ in 2010 the ECtHR held that same sex couples could establish a 'family' life for the purposes of Article 8 ECHR. Also that it would no longer consider that the right to marry enshrined in Article 12 must in all circumstances be limited to marriage between two persons of the opposite sex. However, as matters stood then, the question whether or not to allow same-sex marriage was left to regulation by the national law of the Contracting State. Thus the ECHR did not oblige a State to grant same-sex couples access to marriage. The national authorities were best placed to assess and respond to the needs of society in this field, given that marriage had deep-rooted social and cultural connotations differing greatly from one society to another. ${ }^{172}$ By contrast much less room was afforded for the assessment by national authorities in Vallianatos and Others v. Greece $e^{173}$ in 2013 and in Oliari v Italy ${ }^{174}$ in 2015. In Vallianatos a Law of 2008 made provision for an official form of partnership, 'civil unions', but they were only open to different-sex couples, thereby automatically excluding same-sex couples from its scope. The ECtHR found a violation of Article 14 taken together with Article 8. It observed that of the 19 States parties to the ECHR that authorised some form of

${ }^{168}$ See Alekseyev v. Russia, A. Nos. 4916/07, 25924/08 and 14599/09 (2010). Baczkowski v. Poland, A. 1543/06, (2004) 38 EHRR 24; Baczkowski and Others v. Poland, A. 1543/06, (2009) 48 E.H.R.R. 19; Genderdoc-M v. Moldova, A. 9106/06, (12 June 2012); Vejdeland and Others v. Sweden, A. 1813/07, (2014) 58 EHRR 15, para 55 (a conviction for distributing leaflets offensive to homosexuals was not contrary to Article 10 ECHR); Identoba v Georgia, A.73235/12 (12 May 2015) (domestic authorities failed to ensure that the march to support LGBT rights could take place peacefully by sufficiently protecting the demonstrators from violent counter-demonstrators). Johnson, 'Homosexuality, Freedom of Assembly and the Margin of Appreciation Doctrine of the ECtHR' (2011) 11 Human Rights Law Review 578; Thomas, 'We're Here, We're Queer, Get Used To It: Freedom of Association and Gay Pride in Alekseyev $v$ Russia' (2012) 14 Oregon Review of International Law 505.

${ }^{169} X v$. Turkey, A.24626/09, 9 October 2012.

${ }^{170}$ Pajić v. Croatia, A. 68453/13 (23 February 2016).

${ }^{171}$ A. 30141/04, (2011) 53 EHRR 20. See also Hämäläinen. v. Finland, A. 37359/09, [GC] 37 B.H.R.C. 55.

${ }^{172}$ Repeated in Gas and Dubois v. France in 2012, A. 25951/07. See Hodson, 'A Marriage By Any Other Name: Schalk and Kopf v. Austria' 11 HRLR (2011) 170; Johnson, 'Interpretation and Authority Challenging the Heteronormativity of Marriage: The Role of Judicial Interpretation and Authority' (2011) 20 Social \& Legal Studies 349; Hamilton, 'Why the Margin of Appreciation is Not the Answer to the Gay Marriage Debate' (2013) European Human Rights Law Review 47.

173 A. 29381/09 and 32684/09. See Trispiotis, 'Discrimination and Civil Partnerships: Taking 'Legal' out of Legal Recognition' 14 HRLR (2014) 343.

174 A. $18766 / 11$ and 36030/11 (21 July 2015). 
registered partnership other than marriage, only Lithuania and Greece reserved it exclusively for different-sex couples. In December 2015 the Greek Parliament voted to extend the 2008 Law to same-sex couples. In Oliari the ECtHR found a violation of Article 8 in the based on the inability of homosexual couples to get married or enter into any other type of civil union. The legal protection currently available in Italy to same-sex couples not only failed to provide for the core needs relevant to a couple in a stable committed relationship, but it was also not sufficiently reliable. There was a conflict between the social reality of the applicants, who for the most part lived their relationship openly in Italy, and the law, which gave them no official recognition. In the Court's view, an obligation to provide for the recognition and protection of same-sex unions would not amount to any particular burden on the Italian State. In the absence of marriage, the option of a civil union or registered partnership would be the most appropriate way for same-sex couples like the applicants to have their relationship legally recognised. The Court attached importance to 'continuing international movement towards legal recognition'. ${ }^{175}$ A thin majority (24 out of the 47) Council of Europe member States had legislated in favour of such recognition. Also of relevance was that the highest courts in Italy had repeatedly pointed out the need for legislation to recognise and protect same-sex relationships; that such calls by the Italian courts moreover reflected the sentiments of a majority of the Italian population and that the Italian Government had not denied the need for legal protection of such couples and had failed to point to any community interests against which to justify the applicants 'momentous interests' ${ }^{176}$ Italy had thus failed to fulfil its positive obligation to ensure that the applicants had available a specific legal framework providing for the recognition and protection of same-sex unions. ${ }^{177}$ However, although the finding of a violation of Article 8 was unanimous, for three of the seven judges it was on the basis of different and much narrower reasoning. ${ }^{178}$ Rather than the positive obligations found by the majority, they focused on the defective follow-up, within the Italian legal order, of the Constitutional Courts' declaration of a constitutional entitlement to some form of adequate legal recognition of stable same-sex unions.

The applicants in Oliari also urged the ECtHR to reconsider its approach to the right to marry in Schalk and Kopf v. Austria, and repeated in Hämäläinen v. Finland, ${ }^{179}$ that Article 12 ECHR could not be construed as imposing an obligation on the Contracting States to grant

\footnotetext{
175 Ibid, para 178.

176 Ibid, para 185.

177 On a number of pending applications see 2016 Sexual orientation issues Factsheet, supra $\mathrm{n}$ 161.

${ }^{178}$ See the Concurring Opinion of Judges Mahoney, Tsotsoria and Vehabović.

${ }^{179}$ [GC], A. 37359/09.
} 
access to marriage to same-sex couples. However, the ECtHR considered that despite the gradual evolution of States on the matter (at that time eleven CoE States had recognised samesex marriage) the findings reached in those cases remained pertinent. ${ }^{180}$ It recalled its view in Schalk and Kopf that Article 14, taken in conjunction with Article 8, could not be interpreted as imposing such an obligation. ${ }^{181}$ In March 2016 Italy legislated in response to Oliari. Overcoming strong opposition from the Roman Catholic Church, the Bill provided for legal recognition to same-sex couples via civil union that provide legal rights similar to those of married couples. However, a provision that would have granted non-biological parents in samesex unions some parental rights, known as the 'stepchild' provision, had to be omitted to ensure passage of the legislation.

In cases concerning an alleged clash of non-discrimination rights the ECtHR has accepted that States can afford greater weight to sexual orientation. ${ }^{182}$ In 2013 the ECtHR found no violations in two cases in which the applicants were practising Christians who had been dismissed because they refused to carry out certain duties in the course of employment which they felt would condone homosexuality. It could not be said that national courts had failed to strike a fair balance when they upheld the employers' decisions to bring disciplinary proceedings. In each case the employer was pursuing a policy of non-discrimination against service users, and the right not to be discriminated against on grounds of sexual orientation was also protected under the ECHR. ${ }^{183}$ The ECtHR displayed little sympathy towards the applicant's argument that they had acted on the basis of their religious beliefs and therefore had been discriminated against on the basis thereof. ${ }^{184}$

\section{(c) The Council of Europe - The European Social Charter}

\footnotetext{
${ }^{180}$ Oliari, supra n 174, para 192.

181 Ibid, para 193.

${ }^{182}$ See Hale, 'Religion and Sexual Orientation: The Clash of Equality Rights' (7 March 2014) available at supremecourt.uk/docs/speech-140307.pdf.

${ }^{183}$ Eweida and Others v. UK, A. 51671/10 and 36516/10, (2013) 57 EHRR 8. No violation of
} Article 14 taken in conjunction with Article 9 as concerned Ladele; no violation of Article 9 (freedom of religion), taken alone or in conjunction with Article 14, as concerned McFarlane. Two judges, Vučinić and De Gaetano, dissented in Ladele on the basis that it was a matter of individual moral conscience and that in any event the discriminatory treatment of her was disproportionate.

${ }^{184}$ Cf In 2016 the Northern Ireland Court of Appeal in Ashers Baking Co v Lee, considering an appeal from a decision finding sexual orientation discrimination in the bakery's refusal to supply a cake decorated with a pro-gay marriage campaign slogan, adjourned the case to permit submissions on whether the case also raised freedom of expression issues. 
The European Committee of Social Rights has interpreted the revised European Social Charter (1996), which includes the grounds of 'sex' and 'other status', to extend to discrimination on grounds of sexual orientation. ${ }^{185}$ Specific reference to the rights of LGBT persons in the case law of the Committee has become more frequent. In its decision in Interights v. Croatia ${ }^{186}$ the Committee found that homosexuals were described and depicted, in the context of sexual and reproductive health education, in a particularly negative and distorted manner, leading to a violation of Article 11(2) (right to protection of health) in the light of the non-discrimination clause. As a result of the decision, the Croatian authorities withdrew the impugned school manual.

(d) The European Union and the Charter of Fundamental Rights of the European Union.

For the European Union's 28 member States discrimination on the grounds of sexual orientation is prohibited under the Treaty on the Functioning of the European Union. ${ }^{187}$ Article 21 of the Charter of Fundamental Rights of the European Union on 'non-Discrimination' specifically includes sexual orientation as a prohibited ground. ${ }^{188}$ Article 9 defines marriage in a gender neutral manner but the right 'shall be guaranteed in accordance with the national laws governing the exercise of these rights'. The accompanying Commentary stated that there was 'no explicit requirement that domestic laws should facilitate such marriages. ${ }^{189}$ Moreover, the Charter does not extend the scope or field of application of EU law. Article 21 only addresses discriminations by the institutions and bodies of the EU themselves, when exercising powers conferred under the Treaties, and by Member States when they are implementing Union law (though this is widely

\footnotetext{
${ }^{185}$ European Committee of Social Rights, Conclusions 2006 Vol 1 (Albania) 28, available at http://www.coe.int/t/dghl/monitoring/socialcharter/conclusions/Year/2006Vol1_en.pdf ${ }^{186}$ Complaint No. 45/2007, decision on the merits of 30 March 2009, paras 60-61, available at https://www.coe.int/t/dghl/monitoring/socialcharter/complaints/CC45Merits_en.pdf.

${ }^{187}$ See Articles 10 and 19, Official Journal of the European Communities, C 83/47. It entered into force in 2009. For criticism of pre-accession assessments, see Kochenov, 'Democracy and Human Rights - Not for Gay People?' (2007) 13 Texas Wesleyan Law Review 459.

188 Official Journal of the European Communities, Doc 2000/C 364/01.

${ }^{189}$ Commentary of the Charter of Fundamental Rights of the European Union, prepared in 2006 by the EU Network of Independent Experts on Fundamental Rights, 102, http://ec.europa.eu/justice/fundamental-rights/files/networkcommentaryfinal_en.pdf.
} 
interpreted). ${ }^{190}$ More generally, EU equality and anti-discrimination legislation includes express reference to sexual orientation. ${ }^{191}$ Most rulings of the Court of Justice of the European Union (CJEU) that touch upon sexual orientation issues have related to financial and economic matters. ${ }^{192}$ This includes non-discrimination and equality in labour law, recruitment and pension rights. ${ }^{193}$

In June 2012 the Council of the EU adopted the Strategic Framework on Human Rights and Democracy. ${ }^{194}$ It included a commitment that EU member States and the European External Action Service (EEAS) will work together to develop a strategy on cooperation with third countries on the human rights of LGBT people, including through the UN and the CoE. ${ }^{195} \mathrm{In}$ 2013 the Council of the EU adopted Guidelines to promote and protect the enjoyment of all human rights by lesbian, gay, bisexual, Transgender and intersex persons. ${ }^{196}$ The Guidelines support the promotion and protection of LGBT rights in foreign policy, including development cooperation. In 2013 the EU's Fundamental Rights Agency published an EU-wide LGBT survey. ${ }^{197}$

(e) Organization for Security and Cooperation in Europe (OSCE)

${ }^{190}$ See Kilpatrick, Commentary on Article 21, in S. Peers et al, The EU Charter of Fundamental Rights (Oxford: Hart, 2014), 579-603; Dougan, 'Judicial Review of Member State Action Under the General Principles and the Charter: Defining the "scope of Union law" (2015) 52 Common Market Law Review 1201.

${ }^{191}$ See Directive 2000/78/EC, the Framework Equal Treatment Directive, [2000] OJ L303/16, Article 1; O'Cinneide, 'The Constitutionalization of Equality Within the EU Legal Order: Sexual Orientation as a Testing Ground' (2015) 22 Maastricht Journal of European and Comparative Law 370.

${ }^{192}$ See, for example, Römer v. Freie und Hansestadt Hamburg, judgment (Grand Chamber), Case C-147/08 (Grand Chamber), (2013) 2 C.M.L.R. 11; Hay v Crédit agricole mutuel de Charente-Maritime et des Deux-Sèvres, Case No C-267/12, (2014) 2 C.M.L.R. 32.

${ }^{193}$ See also its rulings on refugees, infra Part 5(e).

${ }^{194}$ See http://www.consilium.europa.eu/uedocs/cms_data/docs/pressdata/EN/foraff/131181.pdf.

$195 \mathrm{http}: / /$ eeas.europa.eu/human_rights/lgbt/index_en.htm.

${ }^{196}$ Available at http://www.consilium.europa.eu/uedocs/cms_Data/docs/pressdata/EN/foraff/137584.pdf. ${ }^{197}$ Available at http://fra.europa.eu/en/publication/2013/eu-lgbt-survey-european-union-lesbiangay-bisexual-and-transgender-survey-results. 
In May 2014 at the OSCE Permanent Council, the Canadian representative decried the fact that, while there was a strong consensus among participating States on responding to acts of intimidation and violence on the basis of race, religion or sex, the same did not hold true when it came to sexual orientation. ${ }^{198}$

\section{(f) The Organisation of American States}

There have been some outstanding developments in the Organisation of American States (35 member States). Since 2008 the General Assembly of the OAS has passed resolutions condemning all forms of discrimination and violence against persons because of their sexual orientation. ${ }^{199}$ However, a number of member States have been unable to join the consensus on the resolutions because there was no national consensus on the issues or they wished to maintain national laws that might be inconsistent with the resolution. ${ }^{200}$ In November 2011 the InterAmerican Commission of Human Rights announced the creation of an LGBT unit in order to strengthen its capacity to protect their rights. ${ }^{201}$ In June 2013 the Organization of American States adopted a resolution asking States to establish mechanisms to combat discrimination based on sexual orientation or gender identity and to protect human rights defenders working on the issue. ${ }^{202}$ In November 2013 the Inter-American Commission on Human Rights became the world's first inter-governmental human rights body to establish a Rapporteur on the Rights of Lesbian, Gay, Bisexual, Trans and Intersex Persons. ${ }^{203}$ In 2013 the OAS adopted the Inter-

${ }^{198}$ Available at http://www.osce.org/odihr/124706?download=true.

${ }^{199}$ See 'Human Rights, Sexual Orientation, and Gender Identity and Expression' AG/RES, 2863 (XLIV-O/14) (5 June 2014) in OAS, General Assembly, Forty-Fourth Regular Session, June 35, 2014, OEA/Ser.P/XLIV-O.2 at 241.

${ }^{200}$ Ibid, fns 1-13, covering 13 member States (out of 35). There was also concern about the expression 'gender identity' was not thoroughly defined internationally or that had international acceptance (St. Vincent and the Grenadines).

201 'IACHR Creates Unit on the Rights of Lesbian, Gay, Bisexual, Trans, and Intersex Persons' available at https://www.oas.org/en/iachr/media_center/PReleases/2011/115.asp. As of 2016 a number of LGBT cases against were pending before the Inter-American Human Rights Commission against Jamaica relating to its anti-gay laws ( $X$ and $Z$, Tomlinson and Henry). Jamaica has not accepted the jurisdiction of the IACtHR. See Tomlinson, 'HIV and Caribbean Law: Case for Tolerance' 29th August 2013, Oxford Human Rights Hub, http://ohrh.law.ox.ac.uk/hiv-and-caribbean-law-case-for-tolerance.

${ }^{202}$ AG/RES. 2807.

203 The current holder of the post is Eguiguren Praeli. See http://www.oas.org/en/iachr/lgtbi/mandate/responsibility.asp. 
American Convention Against All Forms of Discrimination and Intolerance. ${ }^{204}$ Sexual orientation is expressly included among the prohibited grounds of discrimination. ${ }^{205}$ The InterAmerican Convention on Protecting the Human Rights of Older Persons (2015) contained two express references to sexual orientation.

(g) The Organisation of American States and the American Convention on Human Rights

The Inter-American Court of Human Rights (IACtHR) follows much of the substantive jurisprudence and the interpretative approaches of the ECtHR. However, significantly in this context, it does not then explain or justify its decisions by reference to any margin of appreciation afforded to States. ${ }^{206}$ Moreover, the notion of 'regional consensus', which is critical in the ECHR system, rarely figures in its decisions. ${ }^{207}$ In February 2012, the IACtHR decided its first ever sexual orientation discrimination case - Atala Riffo and Daughters v. Chile. ${ }^{208}$ This concerned a Chilean Supreme Court decision resulting in a Chilean mother losing custody of her child because of her sexual orientation. The IACtHR unanimously found violations of the right to equal protection (Article 24), and the right to privacy (Article 11), both in conjunction with general obligation to respect rights in Article 1(1) of the American Convention on Human Rights (AmCHR). That general obligation is owed 'to all persons..., without discrimination for reasons of ..., or of any other social condition'. The express grounds set out in Article 1 did not include sexual orientation so the IACtHR had to determine if it was covered as a 'social condition'. As with the ECtHR, the IACtHR's established approach to interpretation is that human rights treaties are living instruments, whose interpretation must go hand in hand with evolving times and current living conditions. It viewed this evolving interpretation as consistent with the general rules of interpretation set forth in Article 29 of the AmCHR, as well as those established in the Vienna Convention on the Law of Treaties (1969). As the list in Article 1 was merely

\footnotetext{
${ }^{204}$ OAS Treaty A-69, text available at http://www.oas.org/en/sla/dil/inter_american_treaties_A69_discrimination_intolerance.asp. As of 1 January 2016, 9 States has signed the Convention. None had ratified.

205 Ibid, Article 1.

${ }^{206}$ See McGoldrick, 'Affording States a Margin of Appreciation: Comparing The European Court Of Human Rights and the Inter-American Court of Human Rights' in A. Donald et al, (eds), Harmonisation of International Human Rights Law (Brill, 2016, forthcoming).

${ }^{207}$ Neuman, 'Import, Export, and Regional Consent in the Inter-American Court of Human Rights' (2008) 19 European Journal of International Law 101 at 104.

${ }^{208}$ Available at http://www.corteidh.or.cr/index.php/en/decisions-and-judgments.
} 
illustrative, the IACtHR held that the term 'any other social condition' should be interpreted in the manner most favourable option for the human being and in light of the evolution of fundamental rights in contemporary international law. ${ }^{209}$ The IACtHR recited four annual resolutions of the GA of the OAS referring to the protection of persons against discriminatory treatment based on their sexual orientation, ${ }^{210}$ jurisprudence of the ECtHR, the HRC, the Cee ESCR, the Cee Rights of the Child, ${ }^{211}$ the Cee against Torture, ${ }^{212}$ the Cee Elimination of Discrimination against Women, ${ }^{213}$ resolutions from the UN's GA and Human Rights Council ${ }^{214}$ and numerous reports by special rapporteurs of the United Nations to support its conclusion that ...the sexual orientation of persons is a category protected by the Convention. Therefore, any regulation, act, or practice considered discriminatory based on a person's sexual orientation is prohibited. Consequently, no domestic regulation, decision, or practice, whether by State authorities or individuals, may diminish or restrict, in any way whatsoever, the rights of a person based on his or her sexual orientation. ${ }^{215}$

In response to the State's argument the IACtHR pointed out that the alleged lack of consensus in some countries regarding full respect for the rights of sexual minorities could not be considered a valid argument to deny or restrict their human rights or to perpetuate and reproduce the historical and structural discrimination that these minorities had suffered. In support of this point the IACtHR stated that, according to different international and comparative law sources, discrimination against the lesbian, gay, transsexual, bisexual, and intersexual was unacceptable because (i) sexual orientation constituted an essential aspect of a person's identity; (ii) the LGTBI community had been historically discriminated against and the use of stereotypes in treatment towards that community was common; (iii) they constituted a minority that faced greater difficulty in removing discrimination in areas such as the legislative sphere, as well as avoiding negative repercussions in the interpretation of regulations by officials of the executive or legislative branches and in access to justice; (iv) sexual orientation did not constitute a

\footnotetext{
${ }^{209}$ Ibid, paras 83-85.

${ }^{210}$ Ibid, para 86. See supra nn 199-200.

${ }^{211}$ Citing CRC, GC, para 8 (2003), 'HIV/AIDS and the rights of the child'; GC 4, para 6 (2003), 'The health and development of adolescents in the context of the CRC.

${ }^{212}$ Citing CAT Cee, GC No. 2, 'Application of Article 2 by States Parties', CAT/C/GC/2, of January 24, 2008 paras 20, 21.

${ }^{213}$ Citing CEDAW Cee, GR 27, para 13 (2010) (on women of age and the protection of their human rights), 2010, and then Draft of GR 28, para 18 (2010).

${ }^{214}$ Atala Riffo and Daughters v. Chile, paras 78-93.

${ }^{215}$ Ibid, para 91.
} 
rational criterion for the rational and equal distribution or sharing of properties, rights, or social burdens. ${ }^{216}$ The fact that this was a controversial issue in some sectors and countries, and that it was not necessarily a matter of consensus, could not lead the IACtHR to abstain from issuing a decision, since in doing so it must refer solely and exclusively to the stipulations of the international obligations arising from a sovereign decision by the States to adhere to the AmCHR. ${ }^{217}$ On the facts of the case the IACtHR found that sexual orientation had been a decisive factor in the judgment of the Supreme Court. ${ }^{218}$

Significantly, the IACtHR went on to hold that, in the abstract, a child's best interests could not be used to justify discrimination against the parents based on their sexual orientation. A determination based on unfounded and stereotyped assumptions about a parent's capacity and suitability to ensure and promote the child's well-being and development was not appropriate for the purpose of guaranteeing the legitimate goal of protecting the child's best interest. ${ }^{219}$ The IACtHR considered four arguments used by the Supreme Court to protect the best interest of the three girls and that directly related to the mother's sexual orientation - social discrimination, confusion of sexual roles, the mother's privileging of her own personal relationship interests and the right to a normal and traditional family. ${ }^{220}$ In rejecting each argument the IACtHR referred to national and international jurisprudence and expert evidence and reports. The IACtHR also confirmed that the AmCHR did not define a limited concept of family, nor did it only protect a 'traditional' model of the family. It reiterated that the concept of family life was not limited only to marriage and encompassed other de facto family ties in which the parties lived together outside of marriage. ${ }^{221}$

In 2015 the Inter-American Commission on Human Rights referred the case of Homero Flor Freire v. Ecuador ${ }^{222}$ to the IACtHR. The case concerned dismissal from the Army as

\footnotetext{
${ }^{216}$ Ibid, para 93, n 114.

${ }^{217}$ Ibid, para 92.

${ }^{218}$ In this respect it followed E.B. v. France, supra n 164.

${ }^{219}$ Atala Riffo, paras 110-111. Cf Golombok, infra n 393.

${ }^{220}$ Atala Riffo, paras 115-46.

${ }^{221}$ Atala Riffo, paras 143-44, citing ECtHR, Salgueiro da Silva Mouta v. Portugal, supra n 163. In Duque v. Colombia the IAmCtHR applied the approach in Atala Riffo to hold that the State provided no justification objective and reasonable for there to be a restriction on access to a pension survival based on sexual orientation, (22 February 2016).

${ }^{222}$ See Report No. 81/13, Case 12.743, http://www.oas.org/en/iachr/decisions/court/12743FondoEn.pdf. In 2015 the Commission has held admissible an application from a Chilean teacher alleging dismissal from a Catholic school for being a lesbian.
} 
punishment for sexual acts between persons of the same sex. It also held admissible an application from a Chilean teacher alleging dismissal from a Catholic school for being a lesbian.

(h) The African Union

The contrast between the positions in Europe and the Americas with that in Africa is striking. ${ }^{223}$ To the extent that the former can be described as dynamic and progressive, the situation in the AU is somewhere between negative and regressive. It has been suggested that Africa is by far the continent with the worst laws on the books when it comes to homosexuality and other sexual minorities, a phenomenon which is in part rooted in bad colonial-era laws and political situations, religious autonomy, strong beliefs in cultural and family values, and patriarchy. ${ }^{224}$

\section{(i) The African Union and the African Charter on Human and Peoples' Rights}

Article 2 of the African Charter on Human and Peoples Rights (AfCHPR) prohibits discrimination in terms similar to Article 2 of the ICCPR. ${ }^{225}$ There is no reference to sexual orientation but again the list of grounds is illustrative ('such as'). ${ }^{226}$ However, it has been suggested that gaining recognition for 'sexual orientation' as within 'other status' in the nondiscrimination provision in Article 2 AFCHPR appears unlikely. ${ }^{227}$ The African Commission on Human and Peoples' Rights has paid relatively little attention to sexual orientation issues despite significant co-ordinated pressure from NGOs. They have been raised within the reporting

${ }^{223}$ See Maguire, 'The Human Rights of Sexual Minorities in Africa' (2004) 35 California Western International Law Journal 1.

${ }^{224}$ See Itaborahy and Zhu (eds), State Sponsored Homophobia - A World Survey of laws: Criminalization, Protection and Recognition of Same Sex Love, $8^{\text {th }}$ edn, May 2013, 33 available at http://old.ilga.org/Statehomophobia/ILGA_State_Sponsored_Homophobia_2013.pdf; See 'Africa' in Carroll and Itaborahy (eds), State Sponsored Homophobia - A World Survey of laws: Criminalization, Protection and Recognition of Same Sex Love, $10^{\text {th }}$ edn, May 2015, available at http://old.ilga.org.], 101-6 (on action against LGBT NGOs).

${ }^{225}$ See supra Part 2(f).

${ }^{226}$ See Viljoen, International Human Rights Law in South Africa, 2nd edn (Oxford: OUP, 2012), at 259-67. Neither the African Charter on the Rights and Welfare of the Child (1990) or the Protocol to the African Charter on Human nor Peoples' Rights on the Rights of Women in Africa (2003) contain any reference to sexual orientation.

${ }^{227}$ See Johnson, 'Homosexuality and the African Charter on Human and Peoples' Rights: What Can Be Learned from the History of the ECHR?' (2013) 40 Journal of Law and Society 249 at 268. 
procedure. With respect to Cameroon in 2005 the Commission stated that it was 'worried about the upsurge in intolerance towards sexual minorities'. ${ }^{228}$ In Zimbabwe Human Rights NGO Forum v Zimbabwe ${ }^{229}$ in 2006 the Commission stated, obiter, with respect to Article 2, that 'The aim of this principle is to ensure equality of treatment for individuals irrespective of nationality, sex, racial or ethnic origin, political opinion, religion or belief, disability, age or sexual orientation'. ${ }^{230}$ Neither the African Commission nor the African Court on Human and Peoples' Rights (which only delivered its first judgment in 2009) has issued a decision on a sexual orientation discrimination complaint. It has been suggested that individuals have been discouraged from bringing individual complains for fear of establishing negative precedents and engendering a backlash from governments. ${ }^{231}$ A 1994 complaint concerning the criminalization of homosexuality in Zimbabwe was withdrawn in 1995 at the request of the Gays and Lesbians of Zimbabwe who were concerned that the then relatively large amount of de facto freedom would be jeopardized. ${ }^{232}$ Obviously the factual situation in Zimbabwe has significantly deteriorated since that time. ${ }^{233}$ However, in 2010 the African Commission denied the Coalition of African Lesbians (CAL) observer status even though the organisation appeared to meet all the necessary criteria. ${ }^{234}$ The reasons given were that 'the activities of the said Organisation do not promote and protect any of the rights enshrined in the African Charter' and that CAL's objectives were not consonant with the AU Constitutive Act and the African Charter. ${ }^{235}$ This reasoning is difficult to sustain and is inconsistent with the Commission's practice of accepting

${ }^{228}$ Concluding Observations on the Periodic Report on Cameroon, presented to the African Commission on Human and Peoples Rights, 39th Ordinary Session, May 2005, para 15. ${ }^{229}$ Cmn No. 245/02, para 169, available at http://www.achpr.org/files/sessions/39th/comunications/245.02/achpr39_245_02_eng.pdf. ${ }^{230}$ See also 'Sexual orientation under the African Charter on Human and Peoples' Rights' available at http://www.pambazuka.org/en/category/features/68953.

${ }^{231}$ See Murray and Viljoen, 'Towards Non-discrimination on the Basis of Sexual Orientation' (2007) $29 H R Q 86$.

232 'Courson Complaint' available at http://www.galz.co.zw/?page_id=298, referring to Courson $v$ Zimbabwe.

${ }^{233}$ See Barclay, Zimbabwe - Years of Hope and Despair (London: Bloomsbury, 2011).

\footnotetext{
${ }^{234}$ See Vilakazi and Ndashe, 'The day the African Commission disavowed humanity' (2010) available at http://www.pambazuka.org/en/category/features/68947.

${ }^{235}$ Report of the African Commission on Human and Peoples' Rights, Executive Council, 17th Ordinary Session, July 2010, available at http://www.achpr.org/files/activityreports/28/achpr47eo8_actrep28_20092010_eng.pdf.
} 
that the rights in the Charter apply to sexual minorities. ${ }^{236}$ In a significant development in 2014 the African Commission adopted Resolution 275 the 'Protection Against Violence and Other Human Rights Violations Against Persons on the Basis of their Real or Imputed Sexual Orientation or Gender Identity'. ${ }^{237}$ It strongly urged States to end all acts of violence and abuse, whether committed by State or non-state actors, including by enacting and effectively applying appropriate laws prohibiting and punishing all forms of violence including those targeting persons on the basis of their imputed or real sexual orientation or gender identities, ensuring proper investigation and diligent prosecution of perpetrators, and establishing judicial procedures responsive to the needs of victims.

Under Article 60 AfCHPR the African Commission can 'draw inspiration from international law on human and peoples' rights'. The African Court applies the African Charter so should be able to do the same. The African Commission has been strongly influenced by the ECHR jurisprudence. It is interesting to consider whether the Commission and now the Court will follow the ECtHR's jurisprudence on sexual orientation issues as they have in other areas. ${ }^{238}$ There are provisions of the AfCHPR that be used to support sexual orientation complaints, but there are also significant textual differences, in particular, the absence of a right to privacy. ${ }^{239}$ In one sense the domestic situation in many African States looks similar to that which prevailed in Europe between 1950 and 1981 and during which the European Commission rejected applications challenging restrictions on homosexuality. As noted, the fundamental shift in ECHR jurisprudence came with the Dudgeon decision in $1981 .{ }^{240}$ What is different is that the ECtHR could observe that, as compared with the era when the relevant legislation was enacted, there was now a better understanding, and in consequence an increased tolerance, of homosexual behaviour. This understanding and tolerance have not spread in Africa in anything like the same manner. Secondly, the ECtHR could not overlook the marked changes that had occurred in this regard in the domestic law of the member States of the Council of Europe. Again this has not occurred in Africa. If anything there is an increase in repressive legislation (as in Nigeria). ${ }^{241}$ Thirdly, in Northern Ireland the authorities had refrained in the years preceding Dudgeon from

${ }^{236}$ See Viljoen, supra n 226, 266-7; Ndashe, 'Seeking the Protection of LGBTI Rights at the African Commission on Human and Peoples' Rights' (2011) 15 Feminist Africa 17, available at http://agi.ac.za/sites/agi.ac.za/files/2_case_study_sibongile_ndashe.pdf.

${ }^{237}$ See http://www.achpr.org/sessions/55th/resolutions/275.

${ }^{238}$ See Johnson, supra n 227.

${ }^{239}$ Ibid, 261-79.

${ }^{240}$ See supra Part 4(b).

${ }^{241}$ See 'Africa' in State Sponsored Homophobia 2015, infra n 224, 101-6. 
enforcing the relevant criminal law and no evidence had been adduced to show that this had been injurious to moral standards. By contrast prosecutions and convictions have been and are still happening in many African States. ${ }^{242}$ Fourthly, there had not been any public demand in Northern Ireland for stricter enforcement of the law. Again the contrary has been the case in at least some African States. ${ }^{243}$

\section{(j) ASEAN and the ASEAN Human Rights Declaration}

In comparative terms the situation in the ASEAN is also broadly negative and repressive, although developments are complex and mixed. In addition, change tends to be informal rather than formal, incremental rather than dramatic. Colonial criminal laws are gone in Hong Kong, but survive in other former British colonies - Bangladesh, Brunei, India, Malaysia, Myanmar, Pakistan, Singapore, and Sri Lanka. In 2014 Brunei announced that it would introduce a new penal code with death by stoning as a possible punishment for Muslims guilty of rape, adultery, sodomy or extramarital sexual relations. Nonetheless, it has been suggested that overall Asia is becoming more LGBT friendly. ${ }^{244}$ There is no regional ASEAN human rights treaty. It is notable that the most recent international statement of human rights - the ASEAN Human Rights Declaration (2012) failed to mention LGBT rights at all. ${ }^{245}$ During drafting of the Declaration, Malaysia and Brunei, States with majority Islamic populations and which apply Sharia law, strongly objected to the inclusion of rights of sexual orientation and gender identity, as did Singapore. ${ }^{246}$

${ }^{242}$ See Amnesty International, Making Love A Crime: Criminalization of same-sex conduct in Sub-Saharan Africa, 25 June 2013, AI Index: AFR 01/007/2013; State Sponsored Homophobia 2014, supra n 74, 33-40.

${ }^{243}$ For example, there have been prosecutions in Malawi (2010) and in Cameroon. (2012). In Morocco in 2014 a UK national was imprisoned for four months after homosexual images were found on his password-protected phone.

${ }^{244}$ Sanders, 'Asia These Days' in State Sponsored Homophobia 2014, supra n 74, 84-89, and in 2015, supra n 268, 107-13.

${ }^{245}$ Text available at http://www.asean.org/news/asean-statement-communiques/item/aseanhuman-rights-declaration. See Renshaw, 'The ASEAN Human Rights Declaration 2012' (2013) 13 Human Rights Law Review 557.

${ }^{246}$ Amin, 'LGBTIQ Rights Should Be Excluded' 10 September 2012 available at: http://www.malaysiakini.com/letters/208463. The Court of Appeal in Singapore has also upheld the constitutionality of a British colonial provision on homosexuality, see Lim Meng Suang $v$. Attorney-General (2014) SGCA 53, although the law is not generally enforced. Altman and Symons comment that Singapore is 'home to a flourishing gay scene and political movement', supra $\mathrm{n} 14$ at 112 . 
With respect to Arab States, religious teaching based on Sharia law, ${ }^{247}$ conservatism, traditions and conceptions of social order make for an environment which is more hostile to human rights in general and to ideas of sexual orientation discrimination in particular. ${ }^{248}$ Given the views of Arab States in the UN it is unsurprising that the revised Arab Charter on Human Rights 2004 prohibits discrimination but does not mention sexual orientation. Nor indeed does it include a reference to any 'other status'. The Arab Charter has no individual complaints mechanism ${ }^{249}$ and there is no political will to adopt any instrument with a specific reference to sexual orientation. Evidence is provided for this by the fact that the opposing Response to the 2008 Joint Statement on the human rights of LGBT persons sent to the GA was backed by the Arab League. ${ }^{250}$ As noted, the Arab Group at the UN has argued against consideration of the subject of sexual orientation. ${ }^{251}$ It is unlikely, therefore, that there will be many positive developments in this regional area at any time soon.

\section{The Prohibition on Sexual Orientation Discrimination as a National Human} Rights Issue

International human rights bodies vary in whether they specifically look to identify the development of consensus at national level. The ECtHR does but the IACtHR and the HRCee do not. Nonetheless, the probability and legitimacy of international progress on sexual orientation discrimination is undoubtedly linked to such developments. States that oppose recognition of sexual orientation discrimination as a violation of a human right have tended to simply reverse the arguments relating to interpretation and application. They have not been able to deny that human rights apply to 'everyone' but stress that very few national, regional or international provisions prohibiting discrimination expressly refer to sexual orientation. They have criminalized same-sex relationships, which are not considered by them to be protected by the rights to private or family life. They reject the view that sexual orientation falls within 'sex' or

${ }^{247}$ See Rehman and Polymenopoulou, supra n 88. A number of States have made general reservations to obligations under human rights treaties if they are inconsistent with Sharia law. ${ }^{248}$ See State Sponsored Homophobia 2014, supra n 74, at 11-19.

${ }^{249}$ There is a State reporting system. The reports are considered by the Arab Human Rights Committee which can make recommendations.

${ }^{250}$ Supra $n 30$.

${ }^{251}$ See text to supra n 45 . 
'other status'. They regard such an interpretation as going beyond the permissible limits of a living instrument approach to the interpretation of human rights treaties and inconsistent with their object and purpose. Even if such an interpretation of 'other status' was justifiable, these States reject the view that such differential treatment can only be justified by 'particularly serious or weighty reasons'. A lower standard of reasonable and objective reasons is considered applicable. Or, in the alternative, these States argue that they do have 'particularly serious or weighty reasons': ones that reflect their tradition, culture and /or religion. Finally, they would argue that the fact that some international human rights institutions have copied and imitated each other's jurisprudence to reach the contrary result does not make that result justifiable.

A large number of States from different regions have rejected a prohibition on sexual orientation discrimination. Some African political and religious leaders have argued that gay rights are against African traditions, cultural and religious value systems ${ }^{252}$ and African nations have a sovereign right to reject what is seen as an imperialist ${ }^{253}$ or post-colonial imposition by mainly Western nations, ${ }^{254}$ which have sought to affect national sentiment via aid and trade conditionality. ${ }^{255}$ The latter is particularly controversial. ${ }^{256}$ The argument of some African States and leaders is that acceptance of homosexuality is a cultural import of the 'West'. Essentially the same argument has frequently been used to oppose the equality of women and many of the arguments against it are the same. ${ }^{257}$ It disregards the fact that culture and tradition are neither static nor monolithic. Non-heteronormative sexual orientations and gender identities have existed in all world regions, including Africa. Homosexuality has been present in African culture throughout history. ${ }^{258}$ In many African societies, it is not uncommon to acknowledge same-sex relationships. For example, in 2011 a High Court in Kenya upheld the validity of a traditional

${ }^{252}$ Cf. the Asian values debate, on which see Avonius and Kingsbury, Human Rights in Asia: a Reassessment of the Asian Values Debate (Basingstoke: Macmillan, 2008).

${ }^{253} \mathrm{Cf}$. Richards, supra n 12, who argues that gay rights are not a form of imperialism but rather part of an anti-imperialist reaction.

${ }^{254}$ See Hoad, African Intimacies: Race, Homosexuality, and Globalization (Minneapolis: Univ of Minnesota Press, 2007); S. Katyal, 'Exporting Identity' (2002) 14 Yale Journal of Law and Feminism 97 (inherent value of fluidity and deliberation in sexual identity); Okeowo, 'Out in Africa' The New Yorker (24 Dec 2012).

${ }^{255}$ See Gitari, 'Liberation is Within Reach' available at http://ilga.org/ilga/en/article/odQh12r1Oq. On aid conditionality see Part 7 (d) infra. ${ }^{256}$ See Part 7 (d) infra.

${ }^{257}$ See Mullally, Gender Culture and Human Rights: Reclaiming Universalism (Oxford: Hart, 2006); Raday, 'Culture, Religion and Gender' (2003)1 International Journal of Constitutional Law 663; Bamforth (ed), Sex Rights (Oxford: OUP, 2005).

258 ،... while homosexual activity and homoerotic relationships are old and universal, "homosexuals" and lesbian and gay minorities are new', Sanders, supra n 27, at 75. 
Nandi woman-to-woman marriage. ${ }^{259}$ As for the colonialist argument, it has been argued that, historically Africa has always been the friendliest and most tolerant continent, with homosexuality and same-gender behaviours dating back to the time before colonialism and the intervention of Western religion. ${ }^{260}$ The arrival of colonial powers, accompanied by the influence of religious fundamentalism, contributed to criminalisation of homosexuality.261 In fact, it was under British colonial rule that homosexual acts were first criminalised in many of its colonial territories around the world. ${ }^{262}$ Many of those statutory provisions survive. It is thus seriously open to question whether those laws reflect the colonial values or continuing African ones. It has also been observed that no serious or coherent attempt has been made to investigate what distinctive African values might be. ${ }^{263}$ Some doubt on the 'African-ness' of the measure stems from evidence that American evangelical organizations have been complicit in sponsoring what became the 2014 Ugandan Anti-Homosexuality Act. ${ }^{264}$

Some Asia Pacific governments have also marginalized LGBT communities by promoting a narrow conception of 'Asian Values' that emphasizes homogenous rather than diverse societies where the only acceptable norm is heterosexuality. ${ }^{265}$ More generally, Muslim States have consistently opposed the notion of sexual orientation as having no legal foundation in international law and being contrary to Islamic teaching. ${ }^{266}$ The Organization of Islamic

${ }^{259}$ Monica Jesang Katam v. Jackson Chepkwony \& Another (2011) eKLR, available at http://kenyalaw.org/newsletter/20110708.html.

${ }^{260}$ See Itaborahy and Zhu (eds), State Sponsored Homophobia - A World Survey of laws: Criminalization, Protection and Recognition of Same Sex Love, 9th edn, May 2014, 33-35, available at http://old.ilga.org/Statehomophobia/ILGA_SSHR_2014_Eng.pdf. ${ }^{261}$ Ibid.

${ }^{262}$ See Human Rights Watch, This Alien Legacy - The Origins of 'Sodomy' Laws in British Colonialism, available at http://www.hrw.org/en/reports/2008/12/17/alien-legacy-0. Homosexuality was decriminalized in post-Revolution France and its colonies, see Aldrich, 'Homosexuality in the French Colonies' (2002) 41 (3-4) Journal of Homosexuality 201. ${ }^{263}$ See Richards, supra n 12, 221; Sadgrove et al, 'Morality Plays and Money Matters: Towards a Situated Understanding of the Politics of Homosexuality in Uganda' (2012) 50 Journal of Modern African Studies 103; Epprecht, Hungochani: The History of Dissident Sexuality in Southern Africa, 2nd edn (Montreal: McGill-Queens Press, 2013). Article 29 AfCHPR refers to 'positive African cultural values'.

${ }^{264}$ See text to nn 275-77 infra. An alien torts claim has begun against Scott Lively, an evangelical minister in the US, for his role in lobbying for the Ugandan legislation, see Sexual Minorities Uganda v. Scott Lively, C.A. No. 12-cv-30051-Map (Aug. 14, 2013), http://ccrjustice.org/files/SMUG_OrderDenyingDefMTD_08_13.pdf; Bennett-Smith, Scott Lively, "Kill The Gays" Bill Supporter, Says "Right To Sodomy" Is Destroying Human Rights' The Huffington Post, 23 Jan. 2013.

${ }^{265}$ Oslo Conference Report, supra n 6, 20. Cf. the Asian values debate, supra n 252.

${ }^{266}$ See Baderin, International Human Rights and Islamic Law (Oxford: OUP, 2003) at 117. 
Conference (OIC) has been the central forum through which objections have been coordinated. ${ }^{267}$

Significant legislative, policy and judicial developments, both positive and negative, have taken place in a number of States and regions. To gain a sense of the complexity and speed of state practice in terms of developments at the national level it is helpful to assess the broad state of play in 2016 in some critical thematic areas.

(a) Criminalisation of homosexual activities and the prohibition of hate crimes

As of May 2016 homosexual acts were legal in over 119 States. ${ }^{268}$ In regional terms these were drawn from Africa (21), Asia (19), the Americas (24), Oceania (7) and Europe (48). However, some 74 States still retain laws that discriminate against people on the basis of their sexual orientation or gender identity. ${ }^{269}$ That is a very high number and a substantial proportion of States (39\% of UN Member States). In regional terms the 74 are drawn from Africa (34), Asia (23), the Americas (11) ${ }^{270}$ and Oceania (7). ${ }^{271} 41$ Commonwealth member States still criminalize homosexuality. ${ }^{272}$ In 13 States, or parts thereof, the death penalty may be applied to those found guilty of offences relating to consensual same-sex relations. There have been reported executions of four men on homosexuality charges in Iran. ${ }^{273}$ The States that criminalize

\footnotetext{
${ }^{267}$ So too concerning the campaign on defamation of religions, see Langer, Religious Offence and Human Rights: The Implications of Defamation of Religions (Cambridge: CUP, 2014). ${ }^{268}$ See Carroll, State-Sponsored Homophobia - A World Survey of Sexual Orientation Laws: Criminalization, Protection and Recognition (1 $1^{\text {th }}$ edition, May 2016), at 34-6, available at http://old.ilga.org. The figures can be confusing because some of the countries are not States or are not UN members.

269 State-Sponsored Homophobia, ibid, at 36-37.

${ }^{270}$ A judgment of the Caribbean Court of Justice is pending concerning a challenge to the mere existence of immigration laws that prevent LGBT people from entering countries as violating freedom of movement in the Caribbean Community and Common Market (CARICOM), see Tomlinson v. Belize and Trinidad and Tobago.

${ }^{271}$ There also three other entities: Cook Islands (New Zealand), Gaza (in the Occupied Palestinian Territory), South Sumatra and Aceh Province (Indonesia).
}

${ }^{272}$ See Lennox and Waites (eds), Human Rights, Sexual Orientation and Gender Identity in The Commonwealth: Struggles for Decriminalisation and Change, Institute for Commonwealth Studies 2013, available at http://commonwealth.sas.ac.uk.

${ }^{273}$ There have been reports of the so-called Islamic State (ISIS), which operates in Iran and Syria, executing homosexuals simply by throwing them off buildings. See Gandar, 'ISIS militants push man from a three-storey building "for being gay", The Independent, 11 December 2014. In August 2015 the UN Security Council held the first informal discussion of LGBT rights, relating to the situations in Iraq and Syria. 
homosexual conduct represent more than two-thirds of the OIC membership. The practical situation in Muslim States is more complex if Sharia law is applied. Indonesia had largely ignored LGBT persons but in March 2015 it was reported that the Indonesian Islamic Authority, the Ulema Council, had issued a fatwa calling for a range of punishments, from caning to the death penalty, for homosexual acts. ${ }^{274} 2016$ saw a number of anti-LGBT statements from political and religious leaders.

The broad picture in Africa is varied. The position in Uganda has attracted a significant level of international attention. The Anti-Homosexuality Bill, first introduced in October 2009, would have imposed the death penalty for certain acts of 'aggravated homosexuality' and prohibited the 'promotion of homosexuality'. ${ }^{275}$ Before the Bill had been adopted into law, its existence was allegedly used to justify a series of repressive measures. ${ }^{276}$ When finally passed, the Uganda Anti-Homosexuality Act 2014 provided for life imprisonment rather than the death penalty. The bill was signed into law by the President of Uganda on 24 February 2014. However, in August 2014, the Ugandan Constitutional Court declared the Act unconstitutional because it was passed without sufficient quorum for a vote in Parliament. Ugandan President Yoweri Museveni commented that his country risked a trade boycott by the West if it reintroduced the anti-gay $\operatorname{law}^{277}$ and the government has not appealed the ruling to the Supreme Court. In another recent development of note, Nigeria's Same Sex Marriage Prohibition Act (2014) outlawed homosexuality. ${ }^{278}$ In Tanzania, and Sierra Leone, as well as Uganda, offenders can receive life imprisonment for homosexual acts. ${ }^{279}$ At the same time, as well as homosexual

274 'Indonesia's Islamic authority calls for death penalty for gay sex' available at http://www.gaystarnews.com/article/indonesias-islamic-authority-calls-death-penalty-gaysex160315.

${ }^{275}$ See Englander, 'Protecting the Human Rights of LGBTI People in Uganda in the Wake of Uganda's “Anti Homosexuality Bill, 2009”' (2011) 25 Emory International Law Review 1263; Okeowo, supra n 254.

${ }^{276}$ See 'Legislative restrictions on "homosexual propaganda" as a threat to LGBT human rights defenders' International Commission of Jurists, Submission to the Human Rights Council, A/HRC/22/NGO/11, (11 February 2013).

${ }^{277}$ See Biryabarema, 'Uganda's Museveni says new gay law risks trade boycott by the West' Reuters, (3 October 2014) available at http://www.reuters.com/article/2014/10/03/us-ugandarights-idUSKCNOHS1DQ20141003.

${ }^{278}$ Among other things, the Act prohibits the 'public show of same sex amorous relationships directly or indirectly'.

${ }^{279}$ See Nell and Shapiro, Resilience amidst adversity: Being gay and African in the new century, available at http://www.atlanticphilanthropies.org/sites/default/files/uploads/ResilienceAmidstAdversity.pdf (The Atlantic Philanthropies and the OTHER Foundation, 2013). 
acts now being legal in some 21 African States, ${ }^{280}$ same-sex sexual activities between adults have never been criminalised in some 11 others.

India provides another example of the mixed nature of developments. In 2009 the High Court in Delhi held that section 377 of the Indian Penal Code (on 'carnal intercourse against the order of nature'), insofar as it criminalised consensual sexual acts of adults in private, violated Articles 21, 14 and 15 of the Constitution. However, in 2013 this was reversed by the Supreme Court in a judgment that was dismissive of alleged discrimination towards sexual minorities, hostile in tone to the 'so-called rights of LGBT persons', considered that the judgments of other jurisdictions (including the US, ECtHR and South Africa) could not be applied blindfolded to decide the constitutionality of a law enacted by the Indian legislature without a critical examination of the conditions, social norms and attitudes in India, and expressed the view that only a miniscule fraction of the country's population constituted lesbians and gays. ${ }^{281}$ The decision in Koushal has attracted criticism. ${ }^{282}$ In February 2016 the Supreme Court decided to refer to issue to a five-judge Constitution Bench for re-consideration. Interestingly, gender rights are better protected in India than homosexual relations. Only a few months later a different division of the Supreme Court cited extensively from foreign jurisdictions to support its innovative decision to recognise not just transgender rights, but a third gender. ${ }^{283}$

As for homophobic hate crimes, as of May 2016 there were some 36 States in which incitement to hatred based on sexual orientation was prohibited. ${ }^{284}$ Most of these were in Europe. In 40 States, if a hate crime was based on sexual orientation, this was considered an aggravating circumstance. ${ }^{285}$ Again most of these laws were found in Europe.

(b) The express prohibition of discrimination on grounds of sexual orientation

An increasing number of States have sought to strengthen human rights protection in the context of sexual orientation discrimination. These are evidenced in the OHCHR, Council of Europe and

280 State-Sponsored Homophobia 2016, supra n 268, 34.

${ }^{281}$ See Suresh Kumar Koushal v. Naz. Foundation and Others, (2014) 1 SCC 1, paras 40, 43 and 52-54; Khaitan, 'Koushal v Naz: Judges Vote to Recominalize Homosexuality' (2015) 78 Modern Law Review 672; Altman and Symons, supra n 14, 58-62.

${ }^{282}$ See Kirby supra $\mathrm{n} 1$.

${ }^{283}$ See NALSA v Union of India (Writ Petition 604 of 2013) (April 2014).

${ }^{284}$ See State Sponsored Homophobia 2016, supra n 268, at 49-50. In the US animus toward gay, lesbian, bisexual, or transgender people is the second-most common motivation for hate crimes. ${ }^{285}$ Ibid, 46-48. 
FRA Reports. ${ }^{286} \mathrm{~A}$ range of new laws have been adopted including laws banning discrimination based on sexual orientation. The age of consent for homosexual and heterosexual acts is now equal as a matter of law in some 103 States, spread among all continents but remains unequal in at least 16 (8 of which are in Africa) ${ }^{287}$ Discrimination in employment based on sexual orientation is legally prohibited in some 70 States (including 8 in Africa and 14 in the Americas), with a further 13 having a Constitutional prohibition of discrimination based on sexual orientation. ${ }^{288}$ In Chile the first ever anti-discrimination law, which included discrimination on the grounds of sexual orientation, known as the 'Ley Zamudio' after a young man who was murdered due to his sexual preferences, came into effect in 2012. ${ }^{289}$ A number of Muslim States have seen legislative and judicial developments that are more positive in terms of sexual orientation discrimination. ${ }^{290}$ Given the critical legal importance of Constitutions it is always significant if States engage in constitutional change that reflects their position on human rights issues. It was notable that in 2014 the Maltese parliament passed an amendment to the country's constitution including sexual orientation among the grounds of prohibited discrimination. ${ }^{291}$ By contrast, in the context of proposed constitutional reforms in Romania in 2013 a Constitutional Forum's proposal to include sexual orientation as a prohibited ground of discrimination provoked such a strong public reaction and protests from religious groups that it was dropped from its final proposal.

The UK is a good example of a State that has been at forefront of the campaign against sexual orientation discrimination both internally and externally. ${ }^{292}$ By contrast the situation with

${ }^{286}$ See supra nn 7, 15, and 131 respectively. In November 2015 the Ukrainian Parliament added provisions to its Labour Code to outlaw discrimination on the basis of sexual orientation. ${ }^{287}$ State Sponsored Homophobia 2016, supra n 268, at 39. In July 2015 the Equal Employment Opportunity Commission in the US ruled that sexual orientation discrimination was already illegal under Title VII of the Civil Rights Act of 1964 on the basis that they necessarily state a claim of discrimination on the basis of sex, David Baldwin v. Department of Transportation, EEOC Appeal No. 0120133080, available at https://www.eeoc.gov/decisions/0120133080.pdf. 288 State Sponsored Homophobia 2016, Ibid, at 42-4.

${ }^{289}$ See Human Rights Watch, Annual Report 2013, Chile, available at http://www.hrw.org/world-report/2013/country-chapters/chile?page=3.

${ }^{290}$ See Rehman and Polymenopoulou, supra n 88, 48-50.

${ }^{291}$ See Act No. 10 - Constitution of Malta Amendment Act 2014, available at http://www.parlament.mt/billdetails?bid=442\&l=1\&legcat=13.

${ }^{292}$ See Wintemute, 'Homophobia and United Kingdom Law: Only a Few Gaps Left to Close?' in Trappolin et al, supra $\mathrm{n} 7$ at 233; UK cross-government LGBT Equality Action Plan, Working for Lesbian, Gay, Bisexual and Transgender Equality: Moving Forward, available at https://www.gov.uk/government/uploads/system/uploads/attachment_data/file/85482/lgbtaction-plan.pdf; Bull and Another v. Hall and Another, (2013) UKSC 73, (2014) 1 All E.R. 919; 
respect to issues of sexual orientation discrimination in the Russian Federation has attracted a lot of international criticism and debate. ${ }^{293}$ Russia's official view is that there are no discriminatory policies against lesbian, gay, bisexual or transgender persons in the Russian Federation. ${ }^{294}$ There may be a disconnect between official State policy and political policies and attitudes. It has been reported that the Russian President, Vladmimir Putin, regards the West's promotion of gay rights as exemplifying its decadence and the decaying of its values. ${ }^{295}$ Although many countries in Africa are showing little progress in terms of prohibiting discrimination based on sexual orientation and, more generally, protecting the human rights of LGBT people, there have been some promising developments even in States with hostile laws, policies and practices. ${ }^{296}$ Botswana, Zimbabwe, Mozambique and South Africa have progressive employment acts which set standards for non-discrimination on the basis of sexual orientation. In Kasha and Others $v$ Rolling Stone and Another ${ }^{297}$ the High Court in Uganda found a violation of the rights to dignity, privacy and protection from inhuman treatment where a magazine had published the photos, names and addresses of 100 homosexuals under the heading 'Hang them: they are after our kids!'. The most significant and widespread progress by African governments has been the inclusion of men who have sex with men in National HIV plans and consultation processes to strengthen the response and effectiveness of national HIV responses.

(c) Same-Sex Marriages and Joint Adoption by Same Sex Couples

Northern Ireland Human Rights Commission, Re Judicial Review (2013) NICA 37 (27 June 2013); Etherton, 'Religion, the Rule of Law and Discrimination' (2014) 16 Ecclesiastical Law Journal 265.

${ }^{293}$ Alternative report, Implementation of the ICCPR in the Russian Federation: Sexual

Orientation and Gender Identity Issues, Transgender Legal Defense Project/ Russian LGBT

Network available at http://tbinternet.ohchr.org/Treaties/CCPR/Shared\%20Documents/RUS/INT_CCPR_ICO_RUS_ 17137_E.pdf; Kondakov, 'The Silenced Citizens of Russia: Exclusion of Non-heterosexual Subjects From Rights-based Citizenship' (2014) 23 Social and Legal Studies 151; Sochi 2014: Gay Rights Protests Target Russia's Games' 5 February 2014, available at http://www.bbc.co.uk/news/world-europe-26043872.

${ }^{294}$ Russian Federation - Seventh Periodic Report (2012) under ICCPR, CCPR/C/RUS/7, para 164.

295 'Putin's anti-gay tirade ends pas de deux with Merkel' The Sunday Times, 30 November 2014. On Russia's history of sexuality see Lurie Essig, “"Bury Their Hearts': Some Thoughts on the Specter of Homosexuality Haunting Russia," (2014) 1(3) QED: A Journal in GLBTQ Worldmaking 39.

${ }^{296}$ See Oslo Conference Report, supra n 6 at 23-24.

${ }^{297}$ Miscellaneous Cause 163/2010, High Court of Kampala (30 Dec 2010), available at http://iglhrc.org/sites/default/files/2010\%20Kasha\%20Jacqueline\%20v\%20Rolling\%20Stone.pd f. 
The trend towards legalizing same sex marriage is another indicator of incremental support for non-discrimination on grounds of sexual orientation. ${ }^{298}$ The number of countries that have legalised same-sex marriage is relatively small. As of May 2016 marriage was open for samesex couples in some 22 States or parts thereof (11\% of UN Member States) either on the basis of court rulings or legislation. ${ }^{299}$ In United States $v$. Windsor in 2013 the underlying issues concerned federal tax benefits and tax liabilities. The United States Supreme Court held by 5 votes to 4 that s. 3 of the federal Defence of Marriage Act 1996 violated the Fifth Amendment's guarantee of equal protection of the laws so far as certain tax laws discriminated against persons of the same sex who were legally married under the laws of their State. ${ }^{300}$ The Act defined marriage as the union of a man and a woman. In an historic ruling in 2015, Obergefell $v$. Hodges $^{301}$ another 5:4 majority held that the Fourteenth Amendment required States to license a marriage between two people of the same sex and to recognize a same sex marriage licensed and performed out of State. However, the Court was bitterly divided and neither the majority nor the minority made any reference to international human rights standards or jurisprudence. In Ireland same-sex marriage was approved by a referendum in May 2015. However, some States have reinforced the existing position on marriage. In Hungary in January 2013, a new Constitution entered into force which restricted the definition of marriage as a union between a man and a woman. A new Family Protection Act also came into force that defined the family unit as heterosexual. In 2013 the Australian High Court unanimously found the whole of the Australian Capital Territory's Marriage Equality (Same Sex) Act 2013, which purported to legalise samesex marriage in the ACT, to be inconsistent with the Commonwealth Marriage Act 1961 and of no effect. ${ }^{302}$ However, it also made clear that the Commonwealth had the power to enact samesex marriage legislation. As to status, same-sex couples are offered some rights of marriage via Civil Partnerships, Registered Partnerships, Civil Unions in 18 States. ${ }^{303}$

Another indicator of support for non-discrimination on grounds of sexual orientation relates to the possibility of adoption. As of May 2016 full joint adoption by same-sex couples was only

${ }^{298}$ See Eskridge, 'A History of Same-Sex Marriage' (1993) 79 Virginia Law Review 1419; Lord Wilson, 'Marriage is Made for Man, not Man for Marriage' (18 February 2014), available at https://www.supremecourt.uk/docs/speech-140218.pdf..

${ }^{299}$ See State-Sponsored Homophobia 2016, supra n 268, at 50-1.

${ }^{300}$ No. 12-307, available at http://www.supremecourt.gov/opinions/12pdf/12-307_6j37.pdf.

301576 US__ (2015) (Docket No. 14-556).

${ }^{302}$ The Commonwealth v Australian Capital Territory, (2013) HCA 55.

${ }^{303}$ State Sponsored Homophobia 2016, supra n 268, 51-2. 
legal in 26 States or parts thereof and most of which were in Europe and the Americas. ${ }^{304}$ The only African State was South Africa. The only State in the Asian grouping was Israel.

\section{(d) Gay Pride Marches and Homosexual Propaganda Laws}

State and public support for and opposition to Gay Pride Marches are yet another contemporary indicator of attitudes to sexual orientation discrimination. The marches both celebrate LGBT culture and serve as political demonstrations for more extensive legal rights. Marches have been held in all continents and some have attracted millions of participants. Turkey is the first and only Muslim-majority country in which a gay pride march has been held. Some marches have attracted government support. Others have attracted opposition from protesters. In Serbia in 2010 there were violent clashes between police and groups of protesters. Not until 2014 was a successful parade held. In August 2015 Ukraine banned its Pride march. Since 2002 marches in Israel have been marked by controversy and a series of legal challenges particularly from religious groups. ${ }^{305}$ In July 2015 six people were stabbed by an extremist opponent of the Pride march in Tel Aviv in Israel One of them died. Denial or permission to hold marches or assemblies promoting gay rights or restrictions on them have been held to violate Article 11 (freedom of assembly) and $14 \mathrm{ECHR}^{306}$ and Article 21 ICCPR (freedom of assembly). ${ }^{307}$

The Russian Federation considers that its homosexual propaganda laws do not constitute sexual orientation discrimination but are aimed at the protection of children. Particular international controversy has focussed on bans in the Russian Federation on homosexual propaganda, specifically in relation to minors. ${ }^{308}$ One Republic, eight regions and the City of St Petersburg have passed legislation prohibiting promotion of 'homosexual propaganda' among minors. The legislation has been used to arrest and convict activists holding signs expressing

${ }^{304}$ State Sponsored Homophobia 2016, supra n 268, 53. Second parent adoption was available in 23 states.

${ }^{305}$ See Nehushtan, 'Offensive Expression: The Limits of Neutral Balancing Tests and the Need To Take Sides' (2016) Human Rights Law Review 1 at 22-27; Gross, 'The Politics of LGBT Rights in Israel and Beyond' 46(2) Columbia Human Rights Law Review 81.

${ }^{306}$ See supra $\mathrm{n} 168$.

${ }^{307}$ Alekseev v. Russian Federation, Cmn No. 1873/2009, para 9.4.

${ }^{308}$ See Johnson, " "Homosexual Propaganda" Laws in the Russian Federation: Are They in Violation of the ECHR?' http://papers.ssrn.com/sol3/papers.cfm?abstract_id=2251005; 'Communication from the Russian Federation concerning the case of Alekseyev against Russian Federation' to Committee of Ministers of Council of Europe (15 January 2016), https://wcd.coe.int/com. 
support for equality and affirming LGBT human rights. ${ }^{309}$ In its Decision No. 151-O-O of 19 January 2010 the Russian Constitutional Court held that the prohibition on the promotion of homosexuality did not violate constitutional rights. On 29 June 2013 Russia adopted Federal Law No. 135-FZ aimed at protecting children from information promoting the denial of traditional family values. ${ }^{310}$ The law banned the "promotion of nontraditional sexual relations to minors,' a reference that was universally understood to be lesbian, gay, and bisexual relationships. The Law levied fines for promoting homosexuality. ${ }^{311}$ In September 2014 the Constitutional Court ruled that the law was not in breach of the Constitution. ${ }^{312}$ Wide public support for such propaganda laws has also been reported, as has support from the Russian Orthodox Church. ${ }^{313}$

In February 2013 a group of four UN Special Rapporteurs called on the Russian parliament to discard the draft Bill, but to no avail. ${ }^{314}$ A Human Rights Watch Report in 2014 documented the spread of homophobic and transphobic violence and everyday harassment against LGBT people and activists that had taken place in the lead-up to and aftermath of the adoption of the 2013 anti-LGBT law. ${ }^{315}$ As noted above, in 2012 the HRC held in Fedotova v. Russian Federation, ${ }^{316}$ that the State had not shown that a restriction on the right to freedom of expression in relation to 'propaganda of homosexuality' - as opposed to propaganda of heterosexuality or sexuality generally - among minors was based on reasonable and objective criteria. Applications concerning the prohibition of 'homosexual propaganda' in Russia are now

\footnotetext{
${ }^{309}$ See Sozaev, 'Legislation on the So-Called "Propaganda of Homosexuality Among Minors": An Overview' in The Situation of Lesbian, Gay, Bisexual and Transgender People in the Russian Federation, available at http://www.mhg.ru/english/1E11107.

${ }^{310}$ For the Russian text of "On Amendments to Article 5 of the Federal Law 'On Protecting Children from Information Harmful to their Health and development", see http://www.rg.ru/2013/06/30/deti-site-dok.html.

${ }^{311}$ See, 'Russia's anti-gay 'propaganda law' assault on freedom of expression' Amnesty International, 25 January 2013, http://www.amnesty.org/en/news/russia-anti-gay-propagandalaw-assault-on-freedom-expression-2013-01-25

${ }^{312}$ See Russian Communication on the Alekseyev case, supra n 00.

${ }^{313}$ See Elder, 'Russian Parliament was to consider a Federal anti-gay law' The Guardian, November 2012.

314 'UN rights experts advise Russian Duma to scrap bill on "homosexuality propaganda"” available at http://www.ohchr.org/EN/NewsEvents/Pages/DisplayNews.aspx?NewsID=12964\&LangID=E. See also Wilkinson, supra n 59.

${ }^{315}$ Human Rights Watch, Licence To Harm - Violence and Harassment Against LGBT People and Activists in Russia, (2014) available at http://www.hrw.org/sites/default/files/reports/russia1214_ForUpload_2.pdf.

${ }^{316}$ Cmn No. 1932/2010, (2012).
} 
pending before the ECtHR. ${ }^{317}$ In 2014 the UN Committee on the Rights of the Child recommended that Russia repeal its laws prohibiting propaganda of homosexuality and ensure that children who belonged to LGBT groups or children from LGBT families were not subjected to any forms of discrimination by raising the public's awareness of equality and nondiscrimination on the basis of sexual orientation and gender identity. ${ }^{318}$ In 2013 and 2014, 9 States, including Belarus, Kyrgyzstan and Tanzania, have either passed laws, or parliaments were considering Bills, regarding so-called 'homosexual propaganda' laws. ${ }^{319}$ In 2014 Lithuania introduced a ban on spreading information that would promote sexual relations or encourages the concept of entry into a marriage and creation of a family other than stipulated in the Constitution or the Civil Code. ${ }^{320}$

\section{(e) Asylum and Refugees - persecution on grounds of sexual orientation}

Some very protective jurisprudence on persecution on grounds of sexual orientation has been developed in a refugee context. In 2008 (updated in 2012) the UN High Commissioner for Refugees has published 'Guidelines on International Protection No. 9: Claims to Refugee Status based on Sexual Orientation and/or Gender Identity within the context of Article 1A(2) of the 1951 Convention and/or its 1967 Protocol relating to the Status of Refugees' ${ }^{321}$ In 2011 the UNHCR estimated that at least 42 States had granted asylum to individuals with a well-founded fear of persecution owing to sexual orientation or gender identity. ${ }^{322}$ In 2010 the UK Supreme Court held that it would violate Article 3 ECHR if individuals were be deported to a State in

${ }^{317}$ See Bayev and Others v. Russia, A. 67667/09, 44092/12 and 56717/12. The applications were communicated to the Russian Government on 16 October 2013.

${ }^{318} \mathrm{CRC} / \mathrm{C} / \mathrm{RUS} / \mathrm{CO} / 4-5$, paras 24-5 (25 February 2014). See also para 36 on urgent measures to investigate all information relating to the sexual abuse of children, including LGBTI children.

${ }^{319}$ In 2013, parliaments in Moldova, Hungary and Armenia rejected such Bills. On superpower reactions to such proposed laws see Kucera, 'US and Russia Fight Proxy War Over Gay Rights in Kyrgystan' (2014) Diplomat (23 October 2014).

${ }^{320}$ For the text see http://iglhrc.org/sites/default/files/319-1.pdf.

${ }^{321}$ See Hathaway and Foster, The Law of Refugee Status, 2nd edn (Oxford: OUP, 2014) 442-4. See also the Organization for Refuge, Asylum and Migration (ORAM) which specializes in the protection of exceptionally vulnerable refugees, including LGBTI refugees, http://www.oraminternational.org.

${ }^{322}$ Available at http://www.unhcr.org/509136ca9.html. See also OHCHR Report 2011, supra n 7, 21; Frank, 'Making Sense of LGBT Asylum Claim: Change and Variation in Institutional Contexts' (2012) 44 New York University Journal of International Law and Policy 485; Annicchino, 'The Persecution of Religious and LGBTI Minorities and Asylum Law: Recent Trends in the Adjudication of European Supreme Courts' (2015) 21 European Public Law 571. 
which they would have to hide their sexual identity. ${ }^{323}$ In 2015 it held that there could be, in general, a serious risk of persecution on grounds of sexual orientation without that persecution affecting any particular percentage of the population. ${ }^{324}$ The Australian High Court has also held that homosexuals cannot be obliged to live discretely to avoid being persecuted. ${ }^{325}$ The CJEU has held that, when assessing an application for refugee status, the existence of criminal laws which specifically target homosexuals, supports the finding that those persons must be regarded as forming a 'particular social group' and that the competent authorities cannot reasonably expect, in order to avoid the risk of persecution, an applicant for asylum to conceal his homosexuality in his country of origin or to exercise reserve in expression of his sexual orientation. ${ }^{326}$ It has also established limits to detailed questioning of, and evidence from, refugees seeking asylum on the basis of their sexual orientation. ${ }^{327}$ In 2012 the Italian Supreme Court held that the criminalisation against homosexual acts provided by Article 319 of the criminal code of Senegal was in itself a general condition of deprivation of the fundamental right to live an emotional and sexual life without restrictions. Such criminalisation of homosexual acts by this provision was considered to be in itself a form of persecution. ${ }^{328}$

\section{The Consequences of the Contested Status of Sexual Orientation}

\section{Discrimination as an international human rights law issue}

As has been evidenced, States take diametrically opposite positions on whether a prohibition on sexual orientation discrimination is an 'Existing' Right or a 'New' Right. A substantial body of States do not accept it as an existing right based on a living instrument interpretation of human rights treaties. Nor would they accept it as a new right. Their opposition is reflected in the existence of a significant degree of legislative and judicial practice - including in many States which are legally bound by the relevant human rights treaties - and strong public opposition,

${ }^{323}$ HJ (Iran) and HT (Cameroon) v. Secretary of State for the Home Department (2010) UKSC 31. See also M.E. v. Sweden, ECtHR, A. $71392 / 12$ on whether a short period of discretion can reasonably be expected.

${ }^{324} R$ (Jamar Brown (Jamaica)) v. Secretary of State for the Home Department (2015) UKSC 8 ${ }^{325}$ Appellant S395/2002 v. Minister for Immigration and Multicultural Affairs (2003) 216 CLR 473.

${ }^{326}$ Joined Cases C-199/12 to C-201/12, X, Y and Z v Minister voor Immigratie en Asiel, (2014) 2 C.M.L.R. 16.

${ }^{327}$ A, B and C v. Staatssecretaris van Veiligheid en Justitie, Case C-148-150/13, Grand Chamber, (2015) 2 C.M.L.R. 5.

${ }^{328}$ Ordinanza n. 15981 del 2012, (20 September 2012). 
particularly linked to tradition, culture, religiosity and relative poverty. The divisions between States appear to be fundamental. The widespread and significant opposition from States to this normative rise of sexual orientation discrimination has created a situation in which there is a very serious tension between what is asserted to be clear international human rights law and what are clearly the practices of a large number of States from all regions of the world and marked regional differences. It is notable that both sides of the argument have prayed in aid the same paragraph of the 1993 Vienna Declaration to support their understanding of human rights law. ${ }^{329}$ One side emphasises the 'various historical, cultural and religious backgrounds' that must be borne in mind, while the other points to the "duty of States, regardless of their political, economic and cultural systems, to promote and protect all human rights and fundamental freedoms'. When posed as an abstract question of whether there is an 'Existing' Right or a 'New' Right, there is no possibility of bridging the divide as such. 330

Interestingly, however, it is actually the very fragmented nature of international law that allows such differences to remain unresolved. Where States have accepted human rights treaties they are obviously legally binding on them as such. However, few human rights treaties have a system under which a binding legal interpretation of the treaty is ever reached. To the extent that they do not, it is open to States to adopt and maintain different interpretations of the treaty. ${ }^{331} \mathrm{In}$ very formalistic terms we can look at whether human rights institutions can impose specific obligations on States in relation to sexual orientation discrimination. International law offers only limited possibilities for this. Where the $\mathrm{ECtHR}^{332}$ or the $\mathrm{IACtHR}{ }^{333}$ has issued specific rulings then these are formally legally binding only with respect to the States concerned. Even then those States may comply in the most minimalistic fashion and over lengthy periods of time

\footnotetext{
${ }^{329}$ See supra n 50 .

${ }^{330}$ See Donoho, 'Human Rights Enforcement in the Twenty-First Century' (2006) 35 Georgia Journal of International and Comparative Law 1.

${ }^{331}$ For example, the US does not accept the HRC's approach to the extra-territorial application of the ICCPR, see Concluding observations on the fourth report of the US, CCPR/C/USA/CO/4, para 4 (March 2014). Australia does the not accept the HRC's interpretation of 'arbitrary' under Article 9 ICCPR. The US, the UK and France disagreed with aspects of the HRC's GC 24 on reservations. Of course, States can also indicate a different interpretation by means of interpretative declarations.

${ }^{332}$ See Cali and Koch, 'Foxes Guarding the Foxes? The Peer Review of Human Rights Judgments by the Committee of Ministers of the Council of Europe' (2014) 14 Human Rights Law Review 301.

${ }^{333}$ See Huneeus, 'Courts Resisting Courts: Lessons from the Inter-American Court's Struggle to Enforce Human Rights' (2011) 44 Cornell ILJ 493 (national courts, more than any other branch of government, shirk the Court's rulings).
} 
or not at all. ${ }^{334}$ Of course, the jurisprudence of those respective courts is commonly accorded a high or persuasive status by other States parties and if it is not followed then individual applications may follow where this possibility is open to individuals or NGOs. ${ }^{335}$ For the ECtHR there is mandatory access. Individuals can submit petitions to the Inter-American Commission on Human Rights but its decisions are not legally binding. For the IACtHR access only been accepted by 22 States and all cases must be referred by the Inter-American Commission. Judgments of the CJEU are legally binding but cover only a limited range of issues. There are no individual petitions systems with ASEAN or the Arab League. As noted, with respect to the ICCPR, the General Comments and Concluding Observations of the HRC, and their Views under OP1, are not legally binding but they are authoritative. ${ }^{336}$ States rarely make a formal protest but their subsequent reports and responses to the HRC, and their subsequent practice, make it clear that they do not acquiesce to the HRC's interpretations. The same is true for all of the UN treaty bodies. ${ }^{337}$ The Special Procedures and UPR processes are more in the nature of dialogic and advisory systems and do not result in legally binding outcomes.

Overall then, it is not abnormal for interpretational differences relating to human rights treaties to remain unresolved. This leaves a significant space for contestation and argument at local, national, regional and international levels. If individual States are isolated in their interpretation it may be difficult for them to effectively and credibly maintain their views if there is an overwhelming consensus of States, regional and international human rights institutions and procedures against their interpretation. What is unusual in relation to sexual orientation discrimination is the very large number of States sharing the same interpretational differences. Ultimately, for it to be regarded as legally binding, international law requires the consent of States. Absent where they have accorded national or international human rights bodies the power to take binding legal decisions, State consent is clearly lacking in some regions in the realm of a prohibition on sexual orientation discrimination.

\section{Strategies for Managing the Differences on Sexual Orientation Discrimination Between and Within States}

\footnotetext{
${ }^{334}$ See Hillbrecht, Domestic Politics and International Human Rights Tribunals - The Problem of Compliance (Cambridge: CUP, 2014) who submits that 'compliance with human rights tribunal's rulings is a fundamentally political and strategic decision', at 156.

${ }^{335}$ For example, there have not yet been any adoption cases from Russia.

${ }^{336}$ See Part 3(f) supra.

${ }^{337}$ As noted, some of them are more legalistic in their approach than others.
} 
If the preceding analysis and understanding are broadly correct as a matter of international law, attention needs to be focused on the question of what are the most appropriate legal and strategic responses to manage or bridge the very different and apparently rather polarized views of States on the issues. ${ }^{338}$

\section{(a) The complexity of State practice}

The first strategy is to focus on what unites States rather than divides them. The surveys of international and regional human rights practice in Parts 3-4 above and the national practices in Part 5 above are striking for their variety, diversity and complexity. The situation regarding sexual orientation issues has changed in Western Europe in recent decades but it has moved much further and faster than the rest of the world. The CoE is in the vanguard but even then some significant signs of opposition remain, particularly in States such as the Russian Federation, Moldova and the Ukraine. Within the scope of its competence the EU provides significant protection from sexual orientation discrimination. The OAS has seen minimal development but the IACtHR's uncompromising judgment in the Atala case has brought the issue to the forefront. There is little evidence of development in the AU and next to none in ASEAN or the Arab League. It would be simplistic, however, to present the situation in States and regions as totally good in some and totally bad in others. Thinking in terms of regional blocks opposed to a norm on sexual orientation discrimination is also misleading. For example, it is clear both in Africa and in the ASEAN region that State practice is mixed and in a state of flux. Although a small number of African States have recently seen the introduction of stricter laws on homosexuality and a greater emphasis on enforcement, there is also a clear historic trend towards the decriminalisation of homosexuality. Moreover, it has to be remembered that it was only in 2014 that Europe itself become free of such laws. Similarly, discussion in terms or regional or traditional values or a singular idea of a family belies the historical and social complexity of societies and communities in all regions of the world.

(b) Waiting for Consensus - Affording States a Margin of Appreciation?

${ }^{338}$ See also Altman and Symons, supra n 14, ch.6. 
A UN Assistant Secretary-General for Human Rights has argued that the UN cannot back off and wait until there is consensus among States or at least a broader acceptance that LGBT rights violations require a response. ${ }^{339}$ This is intriguing because, for the ECtHR, the existence of a consensus on an issue can be crucial in determining whether there is a violation and whether a State has remained within its margin of appreciation. ${ }^{340}$ Beginning with Dudgeon the ECtHR has looked for existence of consensus in the practice of the member States of the CoE. ${ }^{341}$ Some $45 \%$ of cases that refer to consensus relate to Article 8 ECHR issues. ${ }^{342}$ Almost all of the sexual orientation cases are in this category. Although the $\mathrm{CoE}$ is portrayed as being at the forefront in terms of sexual orientation discrimination, it is often forgotten that is has proceeded incrementally and by looking to the emergence of consensus. Even in a system with an underlying political consensus, a high level political body with responsibility to monitor the implementation of ECtHR judgments and which is supported by a strong Secretariat, it has still taken decades for State practice in all 47 Member States to fall in line with the ECtHR's jurisprudence on the criminalisation of adult consensual same-sex relations. ${ }^{343}$ The practice of the UN human rights treaty bodies is not to look for consensus and not (at least explicitly) to afford States parties a margin of appreciation. Given the political sensitivity of the issues, the existence of a significant degree of legislative and judicial practice from States inconsistent with a prohibition on sexual orientation discrimination, accompanied by strong public opposition in many States and regions, one might at least question the long-term wisdom of that practice as it leaves a huge gap between the law and the practice.

Another obvious difficulty in affording States a margin of appreciation (MOA) which can be affected by presence or absence of consensus are the much larger number of States concerned (168 parties to ICCPR as compared to 47 parties to ECHR) and the even greater massive disparities between them than between members of the Council of Europe. There is arguably a greater risk or likelihood that the MOA doctrine could be used more to confirm

\footnotetext{
${ }^{339}$ Oslo Conference Report, supra n 6, at p. 39.

${ }^{340}$ See Wildhaber, Hjartarson and Donnelly, 'No Consensus on Consensus' (2013) 33 Human Rights Law Journal 248.

${ }^{341}$ Occasionally, after giving States time to evolve their practice, it has clearly decided to go beyond that consensus. Christine Goodwin v. UK, A. 28957/95, (2002) 35 EHRR 18, concerning the legal regulation of transsexuals is the leading example.

${ }^{342}$ See Wildhaber et al, supra n 339, at 257.

${ }^{343}$ See text to $n 147$ supra.
} 
prevailing social norms than to challenge them, ${ }^{344}$ but that may be an inherent element of a universal system.

Another possibility to consider is whether, even if sexual orientation is treated as within 'sex' or 'other status', the requirement of 'particularly serious or weighty reasons' to justify differential treatment is setting the bar too high. The normal standard of 'reasonable and objective' reasons being sufficient to justify differential treatment might accommodate a broader range of genuine State and public concerns, while still generally encouraging States to raise their standards over time. It would also avoid the two extreme alternatives. Under the first States will continue to maintain that sexual orientation discrimination is not a human rights issue at all. Under the second, sexual orientation discrimination is accepted as a human rights issue but a large number of States take the view that such discrimination is justified for a broad range of traditional, cultural and religious reasons. ${ }^{345}$

\section{(c) Promoting dialogue rather than confrontation}

The UN Human Rights Council is an important political forum for the development of new thinking on human rights. However, tendencies toward politicisation along regional lines have been enhanced in relation to the issue of Sexual Orientation and Gender Identity with voting patterns exposing major divisions. Repeating the resolutions just re-emphasizes the differences. So too when differences on sexual orientation issues impact on other resolutions on the protection of the family or traditional values. ${ }^{346}$ Diplomatic skills and cultural sensitivity suggest a need to focus on building cross-regional initiatives to curb the impression that sexual orientation rights is a 'western' conspiracy against non-western States. ${ }^{347}$ To some extent this is already happening in the Human Rights Council as resolutions on sexual orientation are led by a group of South American States. If the EU as a block seeks to advance sexual orientation issues in resolutions it will meet resistance.

\footnotetext{
${ }^{344}$ See Heinze, supra n 12, (2001) 289, n 32. He also observed that 'If United Nations bodies should ever adopt such a doctrine, seeking favourable developments in a significant number of States before recognizing rights, sexual minorities will have a long wait', at 290. 345 See Moecki, 'Equality and Non-Discrimination' in Moeckli et al, International Human Rights Law, 2nd edn (OUP, 2013) at 157-73.

346 See supra Part 3(b).

${ }^{347}$ See Schlanbusch, 'Sexual Orientation and Gender Identity Rights in the Universal Periodic Review' 57, MA Thesis, available at http://www.upr-info.org/IMG/pdf/schlanbusch__sogi_rights_in_the_upr_-_2013.pdf.
} 
By promoting a dialogic approach, the UPR process arguably offers an alternative to a confrontational and antagonistic process of attempting to enforce politically and legally controversial human rights norms. ${ }^{348}$ More generally the UPR process has 'cast some light on the heterogeneity of States over the issue of decriminalisation of sexual orientation' and, 'gives an insight into the complex political terrain of the criminalisation of sexual orientation and facilitates the construction of a more nuanced understanding of the different issues involved in each case'. ${ }^{349}$ Its political and consensual nature provides a forum which encourages incremental reform with respect to specific aspects of sexual orientation discrimination, rather than rather artificially and unhelpfully dividing States into being either pro or anti sexual orientation discrimination as a human rights issue. But the process needs lots of patient diplomatic alliance building among like-minded States to work. ${ }^{350}$ It is not so helpful if UPR recommendations largely come from one regional grouping and are directed against one or two other regional grouping. ${ }^{351}$

The UPR is ultimately a State-centric process. However, the tripartite reporting and the dialogic structure have provided advocates on sexual orientation issues with the opportunity to use the international space as an amplifier to get issues heard at both national and international levels. ${ }^{352}$ Reports from NGO and other national stakeholders have used the space to expose issues of sexual orientation discrimination. There has been a very large increase in SOGI-related content in submissions from civil society actors from the first UPR cycle compared to the second. The number of State sexual orientation recommendations has simultaneously increased as has the number of States willing to make them. ${ }^{353}$ As noted, so far States have not been willing to move on the fundamentals of their opposition by committing to decriminalization. However, decriminalization may require different strategies and stages depending on the legal system, degree of entrenchment and degree of constitutionality in any particular country. ${ }^{354}$ Thus decriminalization can be viewed as a process towards a goal of non-discrimination on grounds of

${ }^{348}$ Cowell and Milon, supra n 72, 352.

${ }^{349}$ Ibid, 351-2.

${ }^{350}$ On the idea of 'steward' States acting to promote human rights see Hafner-Burton, Making Human Rights a Reality (Princeton: Princeton Univ Press, 2013).

${ }^{351}$ Examples are polygamy and women's inheritance rights.

${ }^{352}$ See Schlanbusch, supra n 347.

${ }^{353}$ Ibid, at 11.

${ }^{354}$ Nell and Shapiro, supra n 279, 78. 
sexual orientation that is to be positively encouraged rather than an absolute indicator ${ }^{355}$ From a practical perspective, achieving moratoriums (such as that in Malawi since 2012), nonenforcement of criminal laws, restricting the scope of applicable offences and educating the public are all elements of the process towards decriminalisation.

Moreover, some States have been more willing to respond more positively in terms of acting against violence based on sexual orientation and police violence, education, and impartial investigations. ${ }^{356}$ Bringing in aspects of public health, ${ }^{357}$ as some of the UN treaty bodies have done, may be a good strategic move. ${ }^{358}$ Even if some States have been opposed to considering sexual orientation issues in these terms, in the long term the impact of the health issues on the rest of the population may force them to do so. For example, one argument is that decriminalization of homosexuality would decrease the propagation of the HIV/ AIDS virus. ${ }^{359}$ In September 2012, Commonwealth Foreign Affairs Ministers agreed with the recommendations of the Eminent Persons Group that there should be non-discriminatory access to treatment for HIV/AIDS and those discriminatory laws that impeded such access should be addressed. ${ }^{360}$ This is notable given that 41 Commonwealth member States still criminalize homosexuality. ${ }^{361}$ One positive element in the ASEAN Human Rights Declaration is the obligation to create a positive environment for persons suffering from communicable diseases, including HIV/AIDS. ${ }^{362}$

\section{(d) Economic Issues/ Aid}

When an issue is politically toxic between and within States it can be helpful to change the perspective and analyse the issue in terms of economic development, about which all States are interested. Thus there may be traction in presenting the case that protecting LGBT rights is

\footnotetext{
${ }^{355}$ See Cowell, 'Decriminalising Sexual Orientation: Three African States Compared' available at http://www.polity.org.za/article/decriminalising-sexual-orientation-three-african-statescompared-2011-11-23.

356 See Part 4(c) supra.

357 The World Health Organization's International Classification of Diseases (1977) listed homosexuality as a mental illness. It was removed in 1990.

${ }^{358}$ See supra n 98; Roseman and Miller, supra n 9, at 329; Saiz, supra n 63; Chua and Gilbert, 'Sexual Orientation and Gender Identity Minorities in Transition: LGBT Rights and Activism in Myanmar' (2015) 37 Human Rights Quarterly 1 at 20 (partnerships with HIV/AIDS INGOs carved out relatively freer and safer sites).

${ }^{359}$ See Rehman and Polymenopoulou, supra, n 88, 43-45. Cf ASEAN Declaration, supra n 245.

${ }^{360} \mathrm{See}$ 'Heads of Government of Commonwealth States adopt key HIV and the law recommendations', http:// www.hivlawcommission.org.

${ }^{361}$ See Lennox and M. Waites, supra n 272.

362 ASEAN Declaration, supra n 245, Article 29(2).
} 
important to poverty reduction and that violations of human rights are likely to have a harmful effect on a State's economy and development. ${ }^{363}$ Aid can be and is used to support an environment in which rights can be claimed on a non-discriminatory basis regardless of sexual orientation. In October 2011, during the Commonwealth Meeting of Heads of State, David Cameron, the UK Prime Minister, threatened to reduce development aid to countries that criminalised homosexuality. The United States has stated announced it would use all available mechanisms, including measures related to development cooperation, to promote the rights of lesbian, gay, bisexual and transgender persons. ${ }^{364}$ In February 2014, the World Bank postponed a US\$90 million loan due to the signing Uganda's Anti-Homosexuality Act. The US cut aid, cancelled a military exercise and imposed visa bans on officials. ${ }^{365}$ Norway is withholding $\$ 8 \mathrm{~m}$ in development aid to Uganda, and Denmark will divert \$9m away from the Ugandan government.

However, the risks of using aid as a human rights strategy on culturally sensitive issues are well known. Aid conditionality can undermine and harm local movements that are working hard to improve understandings of sexual orientation and gender identity in specific local contexts. Prime Minister Cameron's statement resulted in an opposing statement signed by over 100 African social justice activists from a considerable number of countries. ${ }^{366}$ The binary nature of the agenda can be limiting because of the narrow nature of the identities it asserts. There are the same general perceptions of imperialism, neo-colonialism and Western imposition of values. Conditionality of foreign aid only reinforces the argument that homosexuality is a Western construct. ${ }^{367}$ It has been argued that diplomatic ties of aid to 'gay rights' by western allies to African countries have perpetuated greater homophobia in Africa with 'gays' being viewed as

${ }^{363}$ See Lee Badgett, The Relationship Between LGBT Inclusion and Economic Development (US Aid/ Williams Institute, 2014) available at file:///F:/Sexual\%20Orientation/lgbt-inclusion-anddevelopment-november-2014.pdf; Park and Badgett, 'Development and Human rights: Two Complementary Frameworks' in State-Sponsored Homophobia 2016, supra n 268, at 23-29. The UNDP is developing an LGBTI Inclusion Index which will measure aspects of economic, social and cultural exclusion of LGBTI persons, see Beavers, ibid, at 30-1. Analogous arguments have been made in relation to the economic impact of disability discrimination.

${ }^{364}$ See 'Advancing the Human Rights of Lesbian, Gay, Bisexual and Transgender Persons Worldwide: A State Department Priority' US State Department, 28 June 2013, available at http://www.state.gov/r/pa/pl/2013/211478.htm.

${ }^{365}$ See Starkey, 'African Fury Over Sanctions' The Times, 21 June 2014.

${ }^{366}$ See African Men for Sexual Health and Rights (2011) 'Statement of African social justice activists on the threats of the British government to "cut aid" to African countries that violate the rights of LGBTI people in Africa', available from: http://www.amsher.net. On opposition to referring to LGBT rights in the UN's Sustainable Development Goals (2015) see supra n 88. ${ }^{367}$ See Abbas, 'Aid, Resistance and Queer Power', Sexual Policy Watch (SPW Working Paper 7, 2012), available at http://www.sxpolitics.org. 
the stumbling block to access public welfare funding for health, education, shelter and other basic public amenities tied to western funding. ${ }^{368}$ Local tensions and intolerance toward perceived or actual sexual minorities are exacerbated when it is thought that aid is being withheld or redirected in order to ensure special treatment for the 'LGBT' movement. ${ }^{369}$ Tying aid to sexual rights can potentially result in the risk that aid towards education or healthcare, for example, will diminish. Governments can blame the withdrawal of foreign aid on 'LGBT' people, as happened in Malawi in 2011. ${ }^{370}$ The distinction is not always easy to make but it may be better to focus on aid which appears as a reward (a carrot) rather than the withdrawal of aid as a punishment (a stick).

\section{(e) Reporting and Awareness within international institutions}

The UN Secretary-General and the UN High Commissioner for Human Rights have both stated repeatedly that there is an urgent need to challenge homophobia at its roots - through public education, training and information on LGBT issues. ${ }^{371}$ For a former UN High Commissioner for Human Rights, Navi Pillay, the first step in overcoming divisions among States was sustained and informed dialogue. ${ }^{372}$ But out of thousands of human rights-related reports presented to the GA and Human Rights Council over the years, just one - her own one-off report to the Council at the end of 2011, ${ }^{373}$ addressed homophobic violence and discrimination headon. The second, related gap was institutional. Information had been collected by existing human rights mechanisms, on an ad hoc basis. The only discussion among States was the 2012 one-off Panel debate. ${ }^{374}$ This fell far short of what was needed. Violence and discrimination against LGBT people was systematic; the response had to be too. In future, both reporting of these violations and discussion of State responses should be institutionalized and mainstreamed.

\section{(f) Domestic Jurisprudence on sexual orientation}

\footnotetext{
${ }^{368}$ Gitari, supra n 255.

${ }^{369}$ See Dunne, 'LGBTI Rights and the Wrong Way to Give Aid' (2012) Harvard Kennedy School Review, 12, pp. 67-70, available at: http://issuu.com/harvardksr/docs/2012. See also Altman and Symons, supra n 14, 126-31.

${ }^{370}$ See Anguita, 'Aid Conditionality and Respect for LGBT People Rights', Sexual Policy Watch, (2012) available at: http://www.sxpolitics.org/?p=7369.

${ }^{371}$ UN SG, Oslo Conference Report, supra n 6.

${ }^{372}$ UN High Commissioner for Human Rights, Oslo Conference Report, supra n 6, 34-35.

373 OHCHR Report 2011, supra $n 7$.

${ }^{374}$ See supra nn 65-7.
} 
On the basis of comparative domestic experience in Guatemala, Ghana, Nigeria, and South Korea, it has been submitted that a, 'great deal of evidence suggests that the incremental approach might ultimately be a more expedient way to improve international gay rights'. ${ }^{375}$ States are not institutionally monolithic and progress may be made from within States by strategic litigation and advocacy relying on domestic constitutional and legislative equality or non-discrimination provisions, sometimes with the use of international or transnational jurisprudence to assist progressive interpretations. ${ }^{376}$ Such domestic jurisprudence may carry a greater domestic legitimacy and authority than international jurisprudence.

\section{(g) Domestic NGOs and other civil society actors}

Human rights awareness can promote rights activism at the local national level. ${ }^{377}$ International human rights jurisprudence can be incorporated into domestic actors' broader strategies to promote positive legal and policy changes and broaden societal understanding of a given issue. ${ }^{378}$ As with most human rights issues it is critical for advocates against sexual orientation discrimination that they are supported by the engagement of vibrant NGO and civil society actors and the space they occupy. Financial and human resources are almost always limited. The use of modern communication methods, particularly use of videos, films and images on the internet and contacts via social media, allows for NGOs and civil society actors to be established more easily and to communicate more effectively and efficiently. ${ }^{379}$ This would suggest that the strategy should be to focus more on non-governmental networks - academic, professional, civil society, and in particular to support local LGBT civil society groups and to encourage them to build alliances with other rights activists. These alliances should include national human rights

${ }^{375}$ Mittelstaedt, supra n 3, 384.

${ }^{376}$ See Lesnikowski, 'Guaranteeing Legal Rights for Sexual and Gender Minorities in Nepal' in Heymann and Cassola (eds), Making Equal Rights Real (Cambridge: CUP, 2012) 359-88.

377 Chua and Gilbert, supra n 358, 23.

${ }^{378}$ See Cavallaro and Brewer, 'Reevaluating Regional Human Rights Litigation in the TwentyFirst Century: The Case of the Inter-American Court' (2008) 108 American Journal of International Law 768 at 770.

${ }^{379}$ See Gross, 'Post/Colonial Queer Globalisation and International Human Rights: Images of LGBT Rights' (2013) 4 Jindal Global Law Review 98. The downside can be the extensive placement of homophobic material on social media. Satire, parody and joking in relation to sexual orientation will also have to be tolerated, see Sousa Goucha v Portugal, A. 70434/12 (22 March 2016) (SG, a homosexual, claimed that a televised joke, which had included him in a list of best female television hosts, damaged his reputation as it had mixed his gender with his sexual orientation: no violation of Articles 8 or 14 ECHR). 
commissions, some of which have done excellent work on sexual orientation issues. ${ }^{380}$ This kind of solidarity is practically important because States continue to try to obstruct the establishment and operation of LGBT associations ${ }^{381}$ and impose more controls on NGOs, particularly on those with any foreign support or financing, and on civil society space. ${ }^{382}$

\section{(h) Changing Public Attitudes to Sexual Orientation Discrimination}

A Pew Survey in 2013, reported in The Global Divide on Homosexuality, also found huge variance between States and between different regions on the broader question of whether homosexuality should be accepted or rejected by society. ${ }^{383}$ Even within the same country attitudes towards sexual orientation discrimination are often very diverse. While education, dialogue and information are crucial, it has undoubtedly also been the case that national, regional and international legal prohibitions on race and sex discrimination have played an important part in developing and changing public attitudes on those issues. ${ }^{384}$ Quiet diplomacy and engagement have their place. ${ }^{385}$ Of course, laws can play a significant role in establishing and maintaining a social consensus. States sometimes need to lead debates on human rights issues by taking positions of principle, even if it can be argued that in doing so they are making an argument beyond the scope of existing law.

Moreover, most States are complex and contain a range of institutional actors. It is not necessarily the case that the views of States in international forums reflect all of the major institutional actors within those States or public opinion within those States. However, the

${ }^{380}$ State Sponsored Homophobia 2014, supra n 74, 85 citing those in Nepal, South Korea, and Thailand; Hafner-Burton, supra n 350, 164-75.

${ }^{381}$ See Eric Githari v. Non-Governmental Organisation Board and Others (Kenya High Court, 2015) (the refusal of the NGO Coordination Board to register the National Gay and Lesbian Human Rights Commission was unlawful), available at http://kenyalaw.org/caselaw/cases/view/108412/; Rammage and 19 Others $v$ Attorney -General, (CA, Bostwana) (refusal to register LGBT organisation was unlawful and violation of rights of assembly and association), available at http://www.humandignitytrust.org/uploaded/Library/Case_Law/Rammoge_and_ors_v_AG_Bots wana_Judgment_2014-11-14.pdf.

382 See Human Rights Council Resolution 27/31, 'Civil Society Space' (3 October 2014).

${ }^{383}$ Available at http://www.pewglobal.org/files/2013/06/Pew-Global-Attitudes-HomosexualityReport-FINAL-JUNE-4-2013.pdf. See also the ILGA-RIWI 2016 Global Attitudes Survey on LGBTI People, available at http://ilga.org.

${ }^{384}$ On the dilemmas of changing LGBT laws, which can then generate a negative social and political response, or changing attitudes, see Mittelstaedt, supra n 3.

${ }^{385}$ For example, the leading LGBTI organisation in Samoa has been appointed a member of the new advisory board to the National Human Rights Institute. 
significant divisions between States in those forums were reflected in the Pew Center survey, conducted in 39 countries among 37,653 respondents. Its Report found huge variance by region on the broader question of whether homosexuality should be accepted or rejected by society. There was widespread rejection in predominantly Muslim States and in Africa, as well as in parts of Asia and in Russia. The survey evidenced a strong relationship between a country's religiosity and opinions about homosexuality. Acceptance of homosexuality was particularly widespread in countries where religion was less central in people's lives. These are also among the richest countries in the world. There was far less acceptance of homosexuality in countries where religion was central to people's lives. ${ }^{386}$ In poorer countries with high levels of religiosity, few believed homosexuality should be accepted by society. Age was also a factor in several countries, with younger respondents offering far more tolerant views than older ones. ${ }^{387}$ To the extent that this is accurate then views will simply evolve in a more tolerant direction over time. It would also suggest that encouraging debate and spreading information amongst younger persons is likely to have the greatest long term effect. While gender differences were not prevalent, in those countries where they were, women are consistently more accepting of homosexuality than men.

To the extent that high religiosity tends to correlate with opposition to homosexuality it is important to emphasise that religions are not uniform or homogenous and are conscious of the risk of being out of step with evolving societal attitudes. The Pope's Apostolic Exhortation, Amoris Laetitia in 2016 restated the Roman Catholic Church's teaching that there were no grounds for considering 'homosexual unions to be in any way similar or even remotely analogous to God's plan for marriage and family' but also reaffirmed that, 'every person, regardless of sexual orientation, ought to be respected in his or her dignity and treated with consideration, while "every sign of unjust discrimination" is to be carefully avoided, particularly any form of aggression and violence. ${ }^{388}$ Although The Holy See considers that the category of 'sexual orientation' has no recognition or clear and agreed definition in international law, ${ }^{389}$ it has expressed opposition to legal discrimination and violence against homosexuals and to

\footnotetext{
${ }^{386}$ Exceptions were Russia and China which received low scores on the religiosity scale, which would have suggested higher levels of tolerance for homosexuality.

387 The same phenomenon has arguably occurred in relation to racial and religious discrimination.

${ }^{388}$ Post-Synodal Apostolic Exhortation, paras 250-1, available at https://w2.vatican.va. ${ }^{389}$ See Statement of The Holy See Delegation, UNGA (18 December 2008), available at http://www.vatican.va/.
} 
criminal penalties being imposed on them. Along with many other States, it does not see opposition to gay marriage as inconsistent with that view.

A focus on the domestic level also encourages engagement with the actions of influential 'veto-players' in the political process, rather than by the assumption of a new societal or political consensus reflected in the legal reforms introduced. ${ }^{390}$ There is an obvious need for social and cultural changes and to identify and address social attitudes and prejudices. In Burma, for example, there is some evidence that repressive laws and abuses 'in the shadow of the law' are being relaxed but societal attitudes and prejudices remain as formidable obstacles. ${ }^{391}$ Thus attention needs to be focussed on the dismantling of stereotypes and social parameters related to sexual orientation. ${ }^{392}$ There is a strong argument that the increased individual and collective visibility of LGBT persons in all social, economic and cultural spheres is a crucial determinant of both societal change and State identity. ${ }^{393}$

It is clearly the case, however, that there is far less agreement or consensus between States on sexual orientation discrimination in relation to same-sex issues concerning marriage, family life, adoption, sex education and the general education of children in relation to sexual orientation issues. It may seem trite but change in these areas is most likely to evolve as a result of more education and information. There is no doubt that the role of education in challenging and changing attitudes is fundamental. Protection against discrimination based on sexual orientation ultimately depends on societal attitudes, which are crucially linked to education, but also on the existence of adequate laws, policies and political will to implement them, which vary considerably even within the same country. ${ }^{394}$ Research which provides evidence that undermines entrenched societal and institutional attitudes to sexual orientation could have a long term impact, assuming that such research is credible. ${ }^{395}$ Social media is likely to play a critical

${ }^{390}$ See Uitz, 'Lessons from Sexual Orientation Discrimination in Central Europe' (2012) 60 The American Journal of Comparative Law 235. For broader social perspectives on the promotion of human rights see Goodman et al, Understanding Social Action, Promoting Human Rights (New York: OUP, 2012).

${ }^{391}$ See Chua and Gilbert, supra n 358.

392 Cf. Bell, 'Gender Identity and Sexual Orientation: Alternative Pathways in EU Equality Law' (2012) 60 The American Journal of Comparative Law 127.

${ }^{393}$ See PM Ayoub, When States Come Out-Europe's Sexual Minorities and the Politics of Visibility (New York: Cambridge University Press, 2016) (LGBT politics can merge with State identities).

${ }^{394}$ See Discrimination on grounds of sexual orientation and gender identity in Europe, supra $\mathrm{n}$ 147, para 8; Trappolin, et al, supra $n$ 7.

${ }^{395}$ Cf Golombok, Modern Families: Parents and Children in New Family Forms. (Cambridge: CUP, 2015) (whether children flourish dependent on factors other than family structure). 
role at least to the extent that it can challenge State and religious controls on information and discussion. ${ }^{396}$

\section{Concluding Comments}

The struggle to achieve recognition for a human rights based prohibition on sexual orientation discrimination parallels those of developing other existing rights or gaining recognition for "new rights' ${ }^{397}$ Women's rights are also a universal problem with significant differences between States and their respective legal and cultural understandings of equality. But at least there is formal consensual acceptance of women's rights and the accompanying institutional and procedural framework. No State argues that women's human rights are not part of existing international human rights. What arguably distinguishes sexual orientation discrimination claims it has been the geographically widespread political and legal opposition. The UN SecretaryGeneral Ban Ki-moon may consider that discrimination on grounds of sexual orientation is 'one of the great, neglected human rights challenges of our time', but many States and their populations clearly do not. Even when there is a greater degree of acceptance of the problems, the issue is not seen a priority one.

The legal debates on whether there are existing treaty prohibitions will doubtless continue. In the light of the continued opposition from a significant body of States, what is the way forward $?^{398}$ The strategic and policy responses considered in Part 7 will shape the overall national, regional and international pictures, but they are complex and contested. Time, aided by the tolerance of younger persons on the issue, and the ubiquitous character of the internet and social media, may bring greater understanding and acceptance as they have with other grounds of non-discrimination such as race, sex, and more recently disability, but this in not inevitable. ${ }^{399}$

However, there was limited evidence on the progress of children with homosexual parents because this is a relatively recent development).

${ }^{396}$ See Sanders, 'Asia These Days' in State Sponsored Homophobia 2015, supra n 224, at 112. In 2016 a music video about gay love in Kenya was watched over 100, 000 times on YouTube after the Kenyan government banned it, see 'How Kenya's "gay love" video ban backfired', http://www.bbc.co.uk/news/magazine-35775093.

${ }^{397}$ See Clifford, supra n 10; Picq and Thiel (eds), Sexualities in World Politics: How LGBTQ Claims Shape International Relations (Abingdon: Routledge 2015).

${ }^{398}$ See also Karsay, supra n 26, identified the challenges as lack of resources and representation, violence on the ground, polarization at the UN and lack of consensus among civil society, 28-31. ${ }^{399}$ Oslo Conference Report, supra n 6, para 3. On human rights as an endlesss contestation concerning the constitution of the human family see Grear, "Framing the Project" of 
In the meantime, a final but important point to emphasize is that in many of the situations of violence, repression and exclusion considered in increasing number of reports on sexual orientation issues, from all regions of the world, sexual orientation may be relevant in terms of motivation or aggravation, but there would be a human rights violation in any event. ${ }^{400}$ LGBT persons have human rights irrespective of the status of their right to be free from sexual orientation discrimination.

\section{ACKNOWLEDGMENTS}

I am grateful to Aoife Nolan, Mindy Roseman, Sangeeta Shah, Colin Warbrick and two anonymous reviewers for comments on drafts of this article. Responsibility for the views expressed is mine alone.

International Human Rights Law: Reflections on the Dysfunctional "Family" of the Universal Declaration' in Gearty and Douzinas (eds), Human Rights Law (Cambridge: CUP, 2012) 18. 400 See Donnelly, 'The Relative Universality of Human Rights' (2007) 29 Human Rights Quarterly 281 at 304. Obviously sexual orientation is particularly relevant when it is the dominant or decisive factor, for example, when individuals are killed or mistreated solely because of their sexual orientation. Altman and Symons advocate a 'modest agenda' of protection from violence and persecution, supra n 14, at 135. 